\title{
ARTIGOS
}

\section{A IDEALIZAÇÃ̃O DE ROMA E SUA ACEITAÇÃO PELOS CRISTÃOS}

\author{
(Continuaçāo)
}

\section{CAPITULO IV}

\section{ROMA PERANTE OS ESTÓICOS E OS CRISTÃOS}

Julgamos ser assunto fora de dúvida que a crença na perenidade de Roma desenvolveu-se, da época de Augusto em diante, como um elemento religioso de considerável importância na história imperial, contrapondo-se às predições de caráter também religioso que, vindas do Oriente, pregavam a queda da cidade e encontravam motivo de júbilo nesta perspectiva. Mas achamos também evidente que nāo se pode distinguir em tal crença apenas o fundamento religioso, - ou melhor - somos de opiniāo que o grande ponto de partida para a sua formação nāo foi religioso, mas filosófico. A nosso ver, Roma corresponderia à entidade que chegara à concretizaçāo, dentro dos limites das possibilidades terrenas, dos ideais politicos da grande corrente de filosofia estóica, que tāo forte era neste periodo; naturalmente, tais ideais representariam o que de melhor pudesse ser imaginado em matéria politico-social (1) dentro da referida escola e Roma, realizando-os,

\footnotetext{
(1). - Preferimos usar a expressāo "político-social" em virtude da dificuldade de se fazer uma separação perfeita cntre os fatos ou idéias que deveriam ser agrupadas exclusivamente sob o título de "sociais" ou "politicas". A este propósito, torna-se bastante elucidativa a seguinte passagem de Oppenheimer: "Die Begriffe schwanken so stark, dass z. B. Arnold Klöppel in seinem Buche "Staat und Gesellschaft" genau dasjenige staat nennt, was ich als Gesellschaft bezeichnen werde, und umgekehrt genau das "Gesellschaft", was ich "Staat" nenne. Die Unklarheit der Regriffsbildung deutet bereite auf den zweiten inneren Grund vor: die ältere Gesellschaftsphilosophie hat zwischen den beiden Phaenomenen so gut wie niemals unterschieden und niemals scharf unterschieden. Den antiken Schriftstellern gelten beide mehr oder weniger als identisch: jede kleine orranisierte Menschengruppe ist fuer Platon bereits ein staat wihrend unsere. Zeit in der Regel von einer Gesellschaft sprechen würde. Nur betonen die der Stoa mehr geneigten Schriftsteller stïrker den "gesellschaftlichen". die der epikuraeischen Lehre mehr geneigten stitrker den "staatlichen" Charakter der Gemeinschaft, die genau von Natur wegen, diesen'durch Satzung entstanden ist. Diese Gleichsetzung geht dann durch vermittlung der kanonischen Philosophie bis auf die Neureit" " "Stant und Gesellschaft", in "Handbuch der Politik", I, pág. 118). Cf́. Bréhier, "Chrysippe", págs. 266-267.
} 
não poderia ser superada por potencia alguma, o que lhe daria o privilégio de ser a última etapa da história humana. A perenidade. surgiria, então, como um atributo ligado à idéia de perfeiçāo, uma vez que a Roma idealisada serıa a cabeça do organismo político perfeito, - o Principado. Dai para o terreno religioso, a passagem teria sido facilitada pelá influência oriental, - por intermédio da Dea Roma - e pela obra do próprio Augusto (2).

Se investigarmos alguma cousa a respeito da formaçāo de Otaviano, vamos encontrá-lo orientado por filósofos estóicos, como Ário Dídimo de Alexandria e Atenodoro de Tarso (3) que, certamente - incutiram no seu espírito os principios da mesma filosofia política grega da qual Sêneca, o grande estóico do Império antes de Marco Aurélio, tiraria a essência do seu pensamento (4). Nestas condições, julgamos inegável a influência do estoicismo sôbre a própria concepção do Principado de Augusto, apesar da existência de autores que opinam em sentido contrário, como por exemplo, Syme, para o qual seria inútil procurar na supremacia de Augusto a última expressāo de uma doutrina estóica, do govêrno do "melhor cidadāo", mesmo porque Augusto nada mais teria sido do. que um chefe revolucionário, que conquistara o poder por meio da guerra civil (5). Ora, quer nos parecer que dificilmente seria possivel, dentro do desenvolvimento cultural a que chegara a Roma do fim do século I a. C. (6), efetuar-se tão radical transformação na organizaçāo do Estado sem que houvesse um sistema de idéias que norteasse o pensamento do autor dessa reforma. De fato (ninguém discute a evidencia). Augusto conseguiu o poder por meio da guerra civil, da fôrça, portanto; mas parece-nos que nāo se pode tomar o seu regime como um produto exclusivo da fôrça, colocando o fundador do Império em pé de igualdade com qualquer chefe bárbaro que conseguisse impor-se à sua tribo, ou com algum tipo de caudilho vulgar. Isto porque os romanos haviam atingido um elevadíssimo grau de cultura. dispondo de elementos:

(2). - Considerando-se que as crenças ligadas a Roma foram integradas na religião imperial, podemos aplicar-lhes aqui as sectuintes palavras de Toynbee ("A Study of History". V, pag. 647): "... We may observe that political potentates do sometimes succed in establishing a cult when this cult is an expression. not of any genuine religious feeling, but merely of some political sentiment that is masquerading in a religious disguise."

(3). - Homo, "Auguste", pág. 24; Bardon, "Les empereurs et les lettres latines d'Auguste a Hadrien", págs. 10 e ss.; o mesmo autor nota que todos os seus mestres de filosofia foram estóicos (pág. 11) e liga ao estoicismo a obra de Augusto, "Hortationes ad philosophiam" (pág. 23) : Pasquali, "Orazio lirico", pág. 380, sublinha espccialmente o papel do estóico Ário Dídimo como confidente e diretor espiritual de Augusto. Buchan ("Augustus", págs. 20-21), destaca a influéncia de Posidonio sôbre o espirito de otávio.

(4). - Béranger, "Pour une définition du Principat". in "Revue des etudes latines", tomos XXI-XXII, pag. 144. Para Weher, in "Cambridge Ancient History", $X \mathbf{l}$, pág. $36 \overline{7}$, as ideias políticas de Augusto prender-se-iam mesmo ao estóico Panécio, através de Cicero.

(5). - "The Roman revolution", págs. 321-322.

(6). - Cr. Guillemin, "Le public et la vie littéraire à Rome", pág. 39. 
mais do que suficientes para desejarem a adoçāo, ou melhor, a adatação à realidade, de uma forma de governo ideal e que melhor correspondesse às suas aspirações, que eram a paz, o equilibrio interno, mas com a hegemonia sôbre o mundo antigo. E, como dissemos, acreditamos que o sucesso de Augusto foi devido principalmente ao fato de suas concepções politicas - que só podiam ser a expressāo de uma dada formaçāo filosófica, - se acharem enquadradas dentro das idéias estóicas, que dominavam o ambiente romano em matéria politica. Quanto ao elemento fôrça, nāo ficaria êle incluido no passado que Otaviano riscara ao adotar o nome de Augusto? - não se ligaria à Roma "causa malorum", enquanto que o P'rincipe ficaria associado à nova Roma, mantenedora da paz e da prosperidade? - Acreditamos que sim, conforme já o demos a entender no capítulo anterior, onde se encontram as bases para a refutaçāo do ponto de vista expendido por Syme.

De mais a mais, achamos interessante que uma das mais recentes tentativas de conceituaçāo do Principado vá recorrer justamente ao estoicismo, para nele encontrar a base do regimem (7). Uma carta de Augusto a seu neto Caio, que nos foi transmitida por Aulo Gélio (8), constitui-se em documento importantíssimo para mostrar que Augusto compreendia a legitimaçāo da conquista do poder pelo mérito e nāo pela fôrça, e certa passagem de Suetônio confirma ainda a significaçāo do mérito pessoal nas idéias políticas de Augusto (9).

Isto, aliás, nāo poderia ser considerado grande novidade; assim como o prôprio estoicismo não foi criaçāo romana, mas helenistica, também suas influências no campo político nāo se verificaram pela primeira vez em Roma, mas no mundo helenístico. O império de Alexandre já poderia encontrar uma certa relaçāo com a filosofia dos cínicos, precursores do estoicismo, que proclamavam ao sábio cidadāo do mundo (10), cuja política seguia as leis da virtude mais do que as da cidade, razāo porque eram favoráveis a formas de govêrno que dessem margem à aplicaçāo dêstes ideais. Para tanto, evidentemente, havia necessidade de ser rompido o quadro estreito da "Polis" grega; dai a simpatia dos

(7). - Béranger, art. cit..

(8). - "As noites aticas". XV, 7: "Mas peço aos deuses que, o tempo que me resta viver, seja-me permitido passá-lo com boa saúde, num Estado perfeitamente feliz." Cf. importantes comentários de Béranger. art. cit..

(9). - "Augusto", 56: "Jamais recomendou seus filhos ao povo sem acrescentar: "se êles mais tarde o merecerem." Béranger, art. cit., pág. 145 nota que idéias semelhantes surgem em Ovídio, "Pônticas", II, 8, 20 e ss., em Plínio-o-moço, "Panegírico", 7, 4, na "HIistória Augusta", Pert., 6, 9, Tac., 4, 3 etc.. A legitimacắo do exercício do poder pelo mérito pessoal era um princfpio comum a cínicos e a estóicos e, segundo Rostovtzeff, deve-se procurar af a explicacão para a resistência oposta aos Flávios por parte dos filósofos das duas escolas, particularmente no que se refere a Helvidio Prisco ("Historia social y económica del Imperio Romano". I, pags. 229 e 252). Cf. Dudley. op. cit. pag. 135.

(10). - Robin. "La pensée grecque", pág. 203; Westermarck, "Christianity and Morals". pág. 107. 
cinicos por tôdas as formas de organizaçāo politica que fôssem incompativeis com aquela estreiteza, tais como o império persa e, mais ligado aos gregos, o império de Alexandre (11). O macedônico serve a Onesícrito para a representaçāo da aplicaçāo do ideal de Diógenes de cidadania do mundo (12), propagando entre os povos mais selvagens a cultura filosófica dos gregos; segundo Plutarco (13), teria êle manifestado opiniões extraordinàriamente concordantes com o único fragmento que nos foi conservado das obras de Antistenes a respeito de Ciro (14), o que contribui para revelar a ligaçāo entre suas idéias politicas e a filosofia dos cínicos (15).

Após Alexandre, o que se vê de importante no campo filosófico é o aparecimento de novas escolas, entre as quais a estóica, fundada mais ou menos em 300 a. C., por Zeno de Cítio, discipulo de Crates (16) que, por sua vez, o fôra de Diógenes de Sinope. Os estóicos encontraram a expressão adeqüada à concepção de mundo da nova época que se iniciara, e que se caracterizava pelo alargamento de horizontes (17) e, ao contrário dos cínicos, que recomendavam completo retiro em relaçāo à vida politica (18), interessaram-se pela politica helenistica, exercendo influência sôbre vários príncipes do período. Citamos, por exemplo, Esfero do Bósforo, em Esparta sob o govêrno de Cleómenes III e no Egito

(11). - Bréhier, "Histoire de la Philosophie",, 1, pág. 277.

(1.2). - Cf. Uberweg, "Grundriss der Geschichte der Philosophie". I, pág. 168. A respeito de Onesicrito. cf. Dudley, "A History of Cynicism", págs. $39-40$.

(13). - Alexandre, 40 e 41 . Cf. Wendland, "H.R.K.", pág. 44.

(14). - Através de ISpiteto, 4, 6, 20.

(15). - Veja-se, a êste respeito, o interessante trabalho de Fisch, "Alexander and the Stoics", in "American Journal of 1'hilology", vol. LVIII, 1 e.2.

(16). - Cf. Dudley, op. cit., pá.gs. 96-97.

(17). - Wendland. "H.R.K.", pä. 41. A própria região de origem da maioria dos estóicos contribuia para dar-lhes tal largueza de horizontes; Cf. Westermarck, op. loc. cit. e Wendland, op. loc. cit., que assim se expressa: "Die Mehrzahl der älteren Soiker stammt aus dem Osten, aus einem Gebiete der Yölker - und Kulturmischung. So verbinden von vornherein keine engen Fijden sie mit den national hellenischen Anschauungen und historischen Traditionen, und diese historische voraussetzungslosigkeit macht die Stoa vorzüglich geeignet, die neuen Grundlagen des Daseins theoretisch festzulegen." Cf. Brfhier, op. cit., I. pág. 286; Guignebert. "Le Christ", pág. 224: Windelband, "La Filosofia Helenistico-romana". pá.g. $55^{\circ} \mathrm{e}$ ss.; Freyer. "Weltgeschichte Europas", pág. 473: "Nachdem der Grieche nicht mehr Polites ist denn das ist man nur zwischen heimischen Menschen und Göttern wird er Kosmopolit. An die Stelle der faktischen und totalen Bindung tritt in der stärker sich durchmischenden Welt die Gleichheit des Bewusstseins und der Bildung. IEs ist immer so gewesen: wer seiner konkreten IEinordnung beraubt. also privat ist. findet sich mit seinesgleichen in einer universalen Ordnung zusammen."

(18). - Cf. Rostovtzeff, "The social and economic History of the Hellenistic World". II, pág. 1121. Note-se, entretanto, que os estóicos não se apresentaram como reformadores políticos, uma vez que dois princípios principais podem ser destacados no setor politico no estoicismo antigo: 1 - O ś́bio deve ocupar-se de política. isto é; preencher todas as funcões de cidadão e de magistrado, a menos que alguma cousa o impossibilite de cumprir tais obrigacooes.

2 - Indiferença em relação as diversas formas de govêrno. A sua preferência pela monarquia, num sentido prático e não apenas ideal. parece ter-se desenvolvido posteriormente. Cf. Brehler. "Chrysippe", págs. 262-266. 
Ptolemaico (19), e todo o circulo de filósofos da Macedônia, onde Antigono Genatas revelou-se grande admirador de Zeno (a ponto de querer tê-lo como conselheiro e diretor espiritual), e de Cleantes, reunindo ao seu redor um grupo de estóicos em que se destacaram principalmente Arato de Sole. Filônides de Tebas e Perseu de Cítio (20).

Assim, o estoicismo foi dispondo de campo propício para o desenvolvimento de seus ideais politicos e sociais (21), que o próprio Zeno sistematizara numa obra intitulada "A República", celebradissima na Antiguidade (22), mas que só nos chegou fragmentàriamente, graças a pequeno número de alusões e citações devidas a outros autores. A participaçāo dos estóicos na vida politica helenistica foi de enorme importância para a evolução de suas teorias, levando-os a caminhar, de um plano completamente ideal, para outro, talvez menos brilhante, mas mais prático. Na obra de Zeno já se reflete clariḷmente esta mudança: partindo do idealismo anárquico dos cinicos, que o levaria a negar qualquer utilidade à lei (23), a afirmar que "as mulheres deveriam ser de dominio comum dos sábios, cada um usando a que the agradasse (24)" o que poria em perigo a instituiçāo da família - e assim por diante, Zeno acaba por se revelar estóico, e nāo mais cinico, defendendo principios incompativeis com o anarquismo utópico (25). Festa, com bastante clareza, expõe sua opiniāo a respeito desta mudança, como se vê:

"Discipulo de Crates, (Zeno) não quis seguir a tradição do mestre e fundou uma escola própria. Por que? - A razão principal é uma incoerência inevitável a todo sistema racionalista quando, da simples especulação teórica, pretenda passar a exercer uma ação direta sôbre a vida real. Nenhum dos cinicos teria podido iludir-se e querer

(19). - Díggenes Iáércio, VIT, 177. ap. Festa, "I. frammenti degli stoici antichi",' II. pág. 178, fr. 1 e pág. 180, fr. 5; Plutarco, "Vida de Cleómenes", 2 e 11, ap. Festa, op. cit., II, pág. 179, frs. 3 e 4. Robin, op. cit., pág. 411. Cf. Brébier, "Chrysippe". págs. 12-13.

(20) - Díggenes Laércio VII, 6, 3, ap. Festa op. cit., II pá 57, fri. 2 ; cf. Tarn, in "Cambridge Ancient Hlistory", VIr, págs. 203-201; Bréhier, op. cit... I, pág. 289; Bardy, "La conversion au Christianisme durant les premiers siècles". págs. 77-78.

(21). - Rostovtzeff, op. cit.. II., pág. 1110.

(22). - Plutarco. "De Alexandri fortitudine", I, ap. Festa, op. cit., I, pág. 9.

(23). - Festa. op. cit., I, pág. 10; "Se os homens fóssem o que deveriam ser, compreender-se-iam imediatamente entre si, näo teriam necessidade de leis, e constituiriam naturaimente a melhor sociedade civil que so possa desejar. Se, ao contrário, permanecer a diferenca entre os homens, não há lei que possa eliminá-la. Porque. quando nos govêrnos democráticos fala-se em igualdade dos cidadãos, fala-se e acredita-se em algo que é depois desmentido pelos fatos." Cf. Wendland, "H. R. K."., pág. 42.

(24). - Festa, op. cit., I, pág. 22, fr. 21; cf., para os cínicos, Ueberweg, op. cit., r. pá.g. 168.

(25). - "Apprenant à l'homme a se considérer non comme une simple partir, mais comme un membre $d^{\prime}$ un vaste organisme social.... Zenon donne a l'esprit purement négatif et frondeur du cynicisme un espoir positif" (Bidez. J., "La Cité du Monde et la Cité du Soleil chez les Stoîciens", pág. 50, ap. Toynbee, "A Study of History". VI, pág. 1, nota 3). 
transformar a sociedade da época num exército de filósofos mendicantes, de pessoas dispostas a viver "segundo a natureza". na pobreza, na renúncia total a tôdas as comodidades de uma vida civil... Zeno apercebeu-se disto, sentindo-se também, ao que parece, não completamente nascido para manter a atitude imudente e insolente de um Diógenes, e pensou num modo de acomodação, mantendo-se fiel aos principios da escola de Antistenes, sen por isso entrar em luta conı o mundo inteiro. Esta tendência conciliadora podia permitir sua propaganda ainda entre as classes sociais que, de início. deveriam mostrar-se mais contrárias aos cínicos. Assim, o programa máximo, impraticável - pelo menos no momento - cedia lugar a um programa mínimo, suficientemente inofensivo para poder ser aceito sem prevenções de escola (26)."

Tratar-se-ia, assim, em poucas palavras, de uma grande capacidade de evoluçāo que, aliás, contribuia para diferençar os estóicos de seus contemporâneos epicuristas (27) e que, no setor politico, era ainda incentivada pelo contato com a realidade (28). Graças a isto, certamente, encontram-se entre os fragmentos d" "A República" de Zeno, trechos que demonstram certo senso de prática, nada mais tendo de utopia anarquista; veja-se, por exemplo, como se expressa o filósofo a respeito da lei:

"A lei é cousa nobre, sendo um arrazoado que ordena o que se deve fazer e veda o que não se deve fazer. Desta nobreza da lei resulta a nobreza do homem qué segue a lei e a põe em prática, que se diz homem honesto. e daquele que sabe interpretá-la e expô-la, que se diz juriconsulto. Só o sábio pode preencher estas duas funçōes. O estulto não pode ser nem o executor, nem o expositor da lei (29)."

Trata-se, portanto, do mérito pessoal legitimando o exercício de funções legislativas, o que é mesmo expressamentẹ confirmado:

"O justo é tal por natureza, e não em virtude de convenção: dai o motivo do sábio tomar parte na vida pública e especialmente naqueles estados que demonstram um certo progresso para uma constituição perfeita; e a atividade legislativa, e o escrever obras úteis a quem as leia, corresponde própriamente aos homens de valor... (30)."

Subsistem sempre, entretanto, as influências dos principios éticos, as idéias fundamentais do Cosmopolitismo e da Humanidade, da reconciliaçāo e confraternizaçāo gerais de todos os homens, de uma divina lei da natureza, posta em nosso coraçāo e que é superior às restritas leis humanas (31). O mérito pessoal - eis o

(26). - Festa, op. cit.. I, pág. 13; cf. Rostovtzeff, op. cit., II, pág. 1132.

(27). - Robin, op. cit., pág. 410: cf. Waltz. "Vie de Séneque". págs. 39-48.

(28). - Cf. Wendland, "H.R.K." pág. 44: aliás, tal aptidão dos estóicos deveria facilitar o seu sucesso entre os romanos, sempre tão preocupados com o aspecto prático da vida (cf. Friedlaender. "La sociedad Romana", pág. 1131; Hochart. "ktudes sur la vie de Ś́neqque". págs. 42-43).

(29). - Stob., "Écl.". II; II, 102, ap. Festa, op. cit., I, pág. 16, fr. 4. Tais idéias lam contra o anarquismo dos cinicos. é claro (cf. Rodier. "Etu-

(30). - Estobeu, "Ecl." "II, 94, 7, ap. Festa, op. cit., X, pag. 23, fr. 28. Veja-se Bréhier, "Chrysippe", pág. 267-268.

(31). - Wendland, "H.R.K.", pág. 42. 
único critério para o estabelecimento de diferenças entre os homens; e por isto nāo se deveria "distinguir o grego do bárbaro considerando-se a clâmide e a adarga, ou o acinace e o candis, mas sim, tomar o valor como sinal do grego, e a vileza como característica do bárbaro (32)." Explica-se destarte a afirmativa de Plutarco, ao dizer que "A Repúblịca" expõe um ideal cosmopolita: a Humanidade não mais dividida em nações e cidades, mas todos os homens considerados como co-nacionais e co-cidadāos; uma só sociedade, como um só mundo (33).

Em 264 morreu Zeno. Seus ensinamentos continuaram a ser desenvolvidos pelos seus discipulos, até que um. dêles, Panécio de Rodes foi a Roma, ligou-se ao círculo dos Cipiōes e converteu às suas idéias um grupo de romanos, dando, assim, início à éra do estoicismo na cidade (34). Já Tibério Graco sofreu a ascendência de Blóssio de Cumes, revelando uma politica em que se destaca claramente a influência estóica (35), que desde então preparava a atmosfera para "o advento de um Império em que as pro- víncias se sentissem igualadas sob a égide maternal de Roma (36)"; dêste modo, a gigantesca tentativa de monarquia universal de Alexandre lançara nos espíritos a idéia da unidade do gênero humano, o estoicismo a puzera em plena luz, e ao Império Romano caberia a sua realização (37).

(32). - Plutarco, “De Alex. virt.", 329 CD, ap. Festa, op. cit., I, pág. 21,

(33). - Idem, idem, 329 AB, ap. Festa, op. cit., I, pág. 20, fr. 19. Naturalmente, participariam desta sociedade os dignos de formá,-la, como já se viu antes. "The credit for having been the first to catch this vision in the Hellenic World is diputed between Alexander of Macedor and Zeno of Citium by their respective modern Western champions: W. W. Tarn ("Alexander the Great and the Unity of Mankind". London. 1933. Milford) and J. Bidez ("La Cité du Monde et la cité du Soleil chez les Stoïciens,". Paris, 1932, Les Belles Lettres). (Toynbee, "A Study of History" "VT. pA.g. 6, nota 4).

(34). - Cf. Wendland, "H.R.K.", pag. 44: Bailey, in "Cambridge Ancient Historty", VITI. págs. 461 e ss.: Dudley. op. cit.. pá.g. 118-119.

(35). - Fisch, "Alexander and the Stoics" pág. 74; Carcopino, "La République Romaine de 133 à 44 av. J. C.". pág. 1.86; Grenier, "Le génie Romain'. págs. 216-217.

(36). - Carcopino. op. cit. pág. 55: cf. Christ. "Geschichte der griechischen Litteratur" 'II. pág. 355, em que é destacada a importancia de Posidônio: Fisch, op. cit., publicada em 1037, onde se lê a seguinte passagem: "When the second century B. C. brought the expansion of Rome towards world empire, the Middie Stoa of Panaetius and Posidonius turned to the winning of the ruling class at Rome. They worked out a philosophical justification of Roman imperialism. durable enough to serve Italy's purposes in Ethiopia today" (va.g. 7i). Cf. Buchan. "Augustus", pág. 21: "...Posidonius, a Stoic who horrowed from many schools, and who tried to marry the thought. of Greece and the East with Roman tradition. seeking what might be a universal creed for a universal empire."

(37). - Aubertin. "Sénequue et Saint Paul". pág. 314: Windelband, op. cit., pág. 54. Destaquemos aqui a seguinte frase de Bréhier, após tratar do cosmopolitismo entre os estóicos antigos: "Ces idees amenent naturellement, semble-t-il. à celle d'une humanité universelle, dans laquelle les relations morales et individuelles sont plus profondes que les relations politiques. Pourtant nł concluons pas trop vite: ce seront lì les fruits qui mariront à l'époque romaine, dans le moyen stoïcisme, où l'idne de l'humanité universelle est assez bien symbolisece par l'amitié de Panétius et de Scipion" ("Chrysippe", pr.g. 269). 
Ora, com Panécio evidenciou-se ainda a maleabilidade, a capacidade evolutiva do estoicismo (38) que, sem deixar de manter suas caracteristicas fundamentais (39), recorreu a elementos de outras escolas (particularmente da Platônica e da Aristotélica), lançando as bases da filosofia romana; esta, na realidade, foi assinalada pelo ecletismo, tal como o encontramos em Cicero (40). $\mathrm{E}$ acreditamos nāo ser difícil reconhecer-se a participaçāo do estoicismo na doutrina do Principado ciceroniano em que, "assim como o lavrador conhece a natureza do seu campo e o intendente é homem versado em letras, e assim como ambos descem das doces especulações da ciência aos trabalhos efetivos da prática, também o guia de que vos falo conhecerá o direito e as leis. Saberá chegar às fontes de um e de outras; ... Deverá ser versado neste direito supremo, fora do qual nāo há justiça; nāo ignorará o direito civil. Mas assim como o piloto estuda astronomia e o médico a física, como cada um dêles se utiliza para o exercicio de uma arte, também êle subordinará tudo à prática (41)." É claro que se trata de capacidade, do mérito pessoal caracterizando o Princeps, aliado à preocupaçāo prática - traço que já assinalara o estoicismo e que integrava também o espirito romano.

E se tivermos em mente que "na filosofia estóica o mundo aparece concebido como uma só unidade inteligivel, impregnada de razāo, e que a crença estóica num estado universal é simplesmente o aspecto político desta concepção filosófica geral (42)", seremos automàticamente levados a concordar com Toynbee (43), quando êste autor já aponta Cícero como totalmente influenciado pela idéia helênica da "Cosmopolis", apoiando-se na seguinte passagem:

"O homem tem um primordial laço social com Deus na posse comum da Razão - visto gue nada há mais elevado do que a Razão, e que esta mais alta de tôdas as qualidades existe ao mesmo tempo em Deus e no homem. Entretanto, aquêles que têm Razão em comum, têm também em comum a Justa Razão: e desde que Justa Razão é um outro nome para a Lei. nós - sêres humanos - devemos ser considerados como estando associados aos deuses também pelo elo da Lel.

(38). - Cf. Rostovtzeft. "The social and economic History of the Hellenistic World". IT. pag. 1121: "In view of the important part which the actual State plaved in the lives of its pupils. of whom many were statesmen in Rome and Greece. the Middle Stoa made strenuous efforts to reconcjle jts individualism and "cosmopolitism" with the State as it existed. which to them again was the citystate. They did not pay so

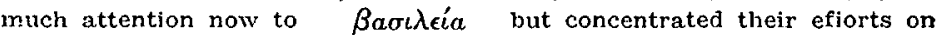
the guidance of statesmen and citizens of the city-state. In this direction the activity of Panaetius was decisive, and in framing his "political" philosophy he had in mind not his influential Roman friends alone."

(39). - Cf. Rodier, "Etudes de philosophie Grecque”, pág. 221.

(40). - Grenier, "Le génie Romain", pág. 201; Beven, "Stolciens et Sceptiques"', pág. 88 .

(41). - "De Re Publica", V, 3.

(42). - Barker, "Wl concepto de Imperio", in "Legado de Roma", pág. 65: Goodenough, "The political philosophy of Hellenistic Kingship'. pág. 58, ap. Fisch, art. cit., pág. 146.

(43). - "A Study of History", VI, pág. 332. 
Mas os que partilham a mesma lei vivem sob a mesma ordem Jurídica, $e$ isto implica em que são membros da mesma comunidade. Se, entretanto, êles estiverem sujeitos às mesmas autoridades $\varepsilon$ poderes, estalo-ão então,a fortiori, à ordem celeste $e$ à Divina Inteligência e ao Deus Tcdo Poderoso. E, assim, o conjunto dêste Universo deve ser considerado como uma única comunidade de deuses e de homens (44)."

- Vivendo numa época em que Roma já chegara a realizar o desêjo de Alexandre, Cícero revelar-se-ia, entāo, um fervoroso defensor das idéias ligadas à República Universal, o que faz com que mereça ser chamado "o mais entusiasmado intérprete da teoria do Pórtico (45)", e não será inútil ressaltar-se aqui a importância de Cicero como um dos preparadores espirituais da época de Augusto, o que já deu margem a que se encontrassem na sua obra as três grandes linhas mestras da literatura do início do Império, que tanto nos tem interessado: a idéia da missāo de Roma, a necessidade de se estabelecer o reinado da Justiça para que tal missāo pudesse ser preenchida e. por fim, a certeza do bem estar para os governados (46). Nāo seria de admirar, entāo, que o Principado de Augusto surgisse sob influência de idéias estóicas, que poderiam ter sido veiculadas pelos mestres de Otaviano, mas numa linha harmoniosa cujo ponto de partida seria Panécio, seguido por Posidonio e pelos discipulos romanos entre os quais incluem-se Varrāo (47) (cujo reflexo sôbre as reformas religiosas de Augusto é bastante conhecido) e, em certa medida, o próprio Cícero (48).

Podemos, agora, retomar o curso do nosso trabalho, voltando à questāo do Principado de Augusto, dando o nosso apôio ao ponto de vista de Béranger; que nos parece totalmente lógico: "O Principado surge como sendo o consórcio de dois principios: u'a mo-

(44). - "De Legibus". I, 7. Cf. Wendland, "H.R.IS.". pág. 41: Christ, op. cit.. IT. phg. 95. assim se expressa a respeito: "Die Stoa... : auch ihr Bild von der Welt als einem liuckenlosen. durch zusammengehaltenen, von der Frde bis zu den Sternen reichenden Organismus hat in seiner Grossztipigkeit eine gewisse Geistesverwandtschaft mit der Idee des Imperium Romanum. und so ist dieser Philosophie unter der Römerherrschaft eine bedeutende Zukunft beschieden gewesen." Boissier. "La religion romaine". II. pag. 5: Fisher. "The beginnings of Christianity", pag. 53: Barth. "Ios istoicos". pag. 222; Moody. "The mind of the early converts". pags. 121-122.

(45). - Aubertin, "Sénèque et Saint Paul". píg. 316.

(46). - Knoche, "Die geistige Vorbereitung der augusteischen Fpoche durch Cicero", in "Forschungen und Fortschritte", 1941, págs. 236-238, ap. Mạrouzeau, "L'annee philologique", XVI, pág. 150.

(47). - Cf. Howald, "Die Kultur der Antike", pág. 191.

(48). - Cicero admirava Panécio como o primeiro dos estóicos ("vel princeps ejus (stoicae) disciplinae; magnus homo et in primis eruditus. gravissimus stoicorum') e, certamente, ouviu I'osidonio, a quem julga um amigo para tôdas as pessoas cultas (familiaris omnium nostrum Posidonius) (Rodier, "śtudes de Philosophie.Grecque", pág. 240) : cf. Fisher, "The beginnings of Christianity", pág. 181. A respeito da predominância do estoicismo na época de Augusto, cf. Skutsch, "Aus Vergils Frtihzeit", páss. 47 e 84, ap. Carcopino, "Tirgile et les origines d'Ostie", pág. 756, nota 11. Para Toynbee, op. cit., págs. 78-79, Augusto seria "The founder of the Hellenic universal state". 
narquia - fruto de um doloroso parto das instituiçōes republicanas - e uma teoria filosófica emanada do pensamento grego, a "Conjunctio potestatis ac sapientiae", que desejava Cicero (49)." O mesmo autor, logo em seguida, nos dá o elemento para afirmar que a base desta teoria era formada pelo estoicismo ou, pelo menos, pelo estoicismo romano, uma vez que Sêneca fazia de Augusto o modêlo sôbre o qual seria conveniente formar Nero (50). Poderíamos acrescentar ainda que a teoria da monarquia fôra desenvolvida pelos estóicos já no mundo helenistico (51), e que o Principado surgira em Roma com u'a monarquia disfarçada; e mais, que os estóicos foram responsáveis por uma justificativa filosófica do imperialismo romano, ligando-se assim de tal maneira à própria idéia imperial (52), que permitiu que se dissesse que "através do estoicismo encontrou sua alma o Império Romano (53)." Repitamos, também, que nos parece completamente falho negligenciar-se a própria formaçāo filosófica de Augusto, bem como sua inclinação para a filosofia (54) - fatos que nāo poderiam ser extranhos ao regime por êle fundado - e sublinhemos mais uma vez a afinidade entre o estoicismo e a "Weltanschauung" dos romanos (55).

(4.9). - Béranger, art. cit., pág. 152. A relação entre as idéias de Cícero e a obra de Augusto é referida também por Toynbee, op. cit., VI, pág. 332, nota 1, com base em Plutarco, "Vida de Cícero", 49.

(50). - Cf. Waltz, "Vie de Séneque", pág. 43; "... le principat d'Auguste... etait bien près pour eux de la perfection"; idem, pág. 247 . Seneca, "De Clementia", VII, VIII, 3: "...; se dizemos claramente que Augusto é o tipo do bom imperador, que o título de Fai da Pátria adaptava-se-lhe bem, ..."; idem, "De Benefitiis", 2, 25, 1; 2, 27, 2; "Apocolokyntosis", X. Cf. Bardon, "Les empereurs et les lettres latines", pág. 254 .

$\mathrm{o}$ exame das teorias referentes as diversas influencias filosóficas que agiram sôbre o Principado exorbitaria do próprio tema de nossa tese. Não podemos deixar, entretanto, de fazer menção do neopitagorismo. Sabenos, por algumas passagens de Filo e de Plutarco, e por um fragmento de Musônio, que as doutrinas pitagóricas achavam-se muito difundidas no perfodo; mas, na medida de-nossos conhecimentos, sabe-se ainda bem pouca cousa a este respeito, o que dá origem a várias questões interessantes, entre as quais destacaremos as seguintes:

a) - Sabe-se que houve relaçöes entre o estoicismo e a escola pitagórica (cf. Aubertin, "Sénèque et Saint Paul", pág. 111). mas que elementos da segunda penetraram a filosofia politica dos estóicos e dos cínicos? (cf. Rostovtzeff, "Historia social y económica del Imperio Romano", I, pág. 251).

b) - Se os pita.góricos tivessem sido realmente responsáveis pela filosofia politica, tanto da realeza helenistica como do imperialismo romano, nâo deverf́amos ouvir algo a seu respeito através dos autores antigos?. (cf. Fisch, "Alexander and the Stoics", pág. 76).

(51). - Cf. Uberweg, op. cit., I, pág. 431. A simpatia dos estóicos pela monarquia foi particularmente acentuada no século I de nossa éra; cf. Dudley, op. cit., pág. 129.

(52). - Fisch, art. cit., pág. 76 ; cf. Brunschvieg, "Le progrès de la conscience dans la philosophie Occidentale", I, pág. 61.

(53). - Arnold, art. "Stolcs", in "Encyclopedia of Religion and Ethics".

(54). - Filo, "Legatio ad Gaium", \$ 309; Sêneca, "13rev. vit.", 4, 2, ap. Beranger, art. cit. pág. 152 .

(55). - Cf. Glover, "The conflict of religions in the early Roman Empire". pag. 39: "This was indeed a philosophy for men, and it was also congenial to Roman character, as history has already shown. It appealed to manhood, and whatever else has to be said of Stoics and Stoicism. it remains the fact that Stoicism inspired nearly all the great characters of the early Roman Empire, and nerved aimost every attempt that was made to maintain the freedom and dignity of human soul"; Buchan, “Augustus", pág. 258. 
Se observarmos os autores da época, ligados que foram à obrá de Augusto, verificaremos que neles se destacam vários traços de influência estóica que contribuem para dar maior fôrça às nossas asserções, como, por exemplo, em Tito Livio (56), Virgilio (57) e principalmente em Horácio, com maior relêvo justamente no III livro de odes, que já vimos ser o mais importante para o nosso tema. Nas odes II, III e IV dêste livro, os comentaristas revelam traços de inspiraçāo do Pórtico, o que nos parece tanto mais interessante quando se trata de poesias constantes do famoso agrupamento de odes civicas (58). Bem sabemos que Horácio é mais geralmente tomado por epicurista, mas julgamos nāo errar se nos apoiarmos na autoridade de G. Pasquali, um dos mais citados especialistas naquele poeta, para afirmar que entre os antigos, em geral, nāo havia uma atitude rígida em relação às diferentes escolas filosóficas, o que explica a facilidade com que o poeta entrelaça pensamentos da Estôa com doutrinas e máximas de Epicuro (59). Isto, aliás, não deixa de ter certa coerència com as caracteristicas assumidas pelos estóicos e às quais já nos referimos antes: a tendência à maleabilidade e a capacidade de absorçāo de elementos de outras escolas; sendo de se notar que a existência de pregadores populares estóicos neste periodo contribuiria para facilitar o desenvolvimento dêstes traços (60).

Saltando-se alguns anos da história do Império e considerando-se a época de Nero, vamos encontrar um fato altamente significativo para nós. Trata-se, nada mais nada menos, do que da reapariçāo, na literatura, dos mesmos temas que vimos desenvolvidos no fim do século I a. C.. Aliás, nas suas linhas gerais, e com menor intensidade, as preocupações do período se assemelham às de que tratamos ao falarmos em Virgílio e Horácio: insatisfa-

\footnotetext{
(56). - Bernecque, "Tite Live", pág. 104; Bardon, op. cit., pág. 64.

(57). - Bardon, op. 10c. cit.; Carcopino, "Virgile et les origines d'Ostie", pág. 778; Glover, "Virgil", págs.' 302-304.

(58). - Villeneuve, trad. Odes e Epodos, pág. 97, nota 4 ; pág. 98, nota 2 ; pág. 102, nota 1. O mesmo autor nota também inspiração estóica em outras peças, assim como na ode II do livro II e nas Epistolas, II, 2, 146. Aliás, a influencia do Portico é visivel em tóda a série das tépístolas, dando margem à afirmativa de que Horácio aderira completamente ao estoicismo (Courbaud, "Horace, sa vie et sa pensée à l'époque des Epitres", ap. Bardon, op. cit., pág. 86, nota 1), ou pelo menos, revelava tal adesão ao dirigir-se ao povo romano (Rabe, "Das Verhältnis des Horaz zur Philosophie" in "Archiv für Geschichte der Philosophie', 1931, pág. 77, apud Bardon, op. loc. cit.). Mesmo esta restrição (combatida por Bardon) não prejudica o nosso ponto de vista.

(59). - Pasquali, "Orazio Lirico", pág. 620: cf. pág. 380: "nell'eta augustea Stoa ed epicureismo, distinti nettamente nel III secolo, tendano a fondersi." Para a filosofia de Horácio na.s sátiras, cf. Cartault, "ftude sur les satires d'Horace", págs. 326 e ss.. (60). - Cf. Villeneuve, "Issai sur Perse", pá. 136; Wendland, "H.R.K.", enough in Rome towards the end of the first century B. C.. as we gather from Horace's references to such persons as Fablus, Crispinus, and Stertinius .... There. is nothing to distinguish them from the Cynics of Hellenistic times as far as their creed goes, but they call themiselves Stoles:...".
} 
çāo com o presente, desconfiança nos destinos do Império (61) e aspiraçāo a algo de melhor, digamos mesmo, à Idade de Ouro, expressamente mencionada por Sêneca (62); a fase marcada pelo govérno de Augusto era encarada com verdadeira saudade (63), e assim como o fundador do Império tivera a Apolo como divindade preferida, também Nero - de quem se esperava a restauraçāo da felicidade perdida $(64)$ - surgia como o protegido de Febo (65).

Nas obras de outros autores há a mesma repetição de temas virgilianos, merecendo ser transcrita, a êste respeito, uma passagem de Bardon, ao referir-se a T. Calpurnius Siculus e ao autor

(61). - Cf. Sêneca, "De Clementia". I, 1: “. . esta imensa população dividida contra si mesma, pronta a revolta, incapaz de se dominar, condenada, se quebrar o seu jugo, a destruir-se ..."; cf. "De Ira"., I, 1.1, 3-4, em que se nota uma verdadeira previsão da quebra de Roma sob os germanos. Cf. Sanford, "Contrasting views of the Roman Empire". págs. 441-442; Waltz, "Vie de Séneque", págs. 154-155.

(62). - "Apocolokyntosis", IV, 1:

"Neste instante Laquesis, uma de suas duas irmãs,

Numa roupa enfeitada de festōes e de flores,

Corn a fronte coroada com lauréis do Permesso,

De um velo de prata tira uma longa trança,

Da qual sua mão hábil faz um fio delicado.

Sobre o fuso, o fio assume um novo brilho:

Com sua rara beleza as irnās ficam admiradas;

E todas a porfia, ornadas de zuirlandas.

Vendo sua lã brilhar e tornar-se ainda mais rica,

Idem, I, 1:

Com um fio dourado tecem o século de ouro.

Cf. Cartas a Lućlio, XC, $36-43$. Bardon, op. cit., pát. 224; Glover.

"The conflict of religions in the early Roman Empire". pág. 36.

Também no "Hercules Furioso", IV, 926 e ss. reflete-se a aspiração À, Idade de Ouro. como se vâ:

" $\mathrm{Bu}$ conceberei uma prece digna de mim. digna de Júpiter. Que permanecam no lugar que lhes foi designado tanto o céu como a terra e o espaço etéreo: que, sem malignidade, os astros sigam seu curso eterno; possa, do alto, a paz nutrir a humanidade, e todo ferro não servir senão aos trabalhos rústicos: para traz as espadas! Possa para sempre a onda não conhecer a tempestade, e o raio não dardejar da ira de meu pai, e nunca mais, alimentado pelas neves de inverno, o rio assaltar os campos e destrui-los. Já basta de venenos: que nenhuma erva mais se torne pesada, cheia de um suco nocivo; cesse a crueldade dos reinados tiránicos!" Cf. Jeanmaire, "La. Sibylle", págs. 87-S8).

(63) - "Apocolokyntosis" X. Nero chegou a ser intitulado "novo Augusto", em moedas alexandrinas da época (cf. Mornigliano, in "Cambridge Ancient History", $\mathrm{X}$, pá.g. 703).

(64) - "Apocolokyntosis", N. 1, 23-24; "De Clementia", I, II, 1.

(65). - "Apocolokyntosis", IV, I:

"Febn, com um canto de alegria, anunciado o futuro,

"A pressa-se a servi-las de fusos sempre novos.

"I procurando na sua lira um tom que as seduza.

"Engana-as com sucesso sobre o tempo que se esgota.

"Possa um tão doce trabalho, diz tele, ser eterno!

"Os dias que fiais não säo os de um mortal:

"nle ser-me-A, semelhante. tanto de aspecto como de rosto,

"Gle terá a fortuna da voz e dos cantos;

"Séculos mais felizes renascerão à sua voz;

"Sua lei fará cessar o siléncio das leis.

"Como se vé a estrela radiosa da manhá

"Anunciar a partida da noite tenebrosa.

"Ou tal como o Sol dissipando os vapores,

"Dá luz ao mundo e alegria aos coraçóes;

"Assim César vai surgir, e a terra fascinada

“Já se regosija aos seus primeiros raios. 
das duas éclogas do "Codex Einsidlensis 266 saec. X": "Os temas dos dois elegiacos sāo os de Sêneca na "Apocol." Em primeiro lugar, a idade de Ouro, tomada a Virgilio. Sêneca. diz ("Apol. 4, 1, 23-24):

felicia lassis

saecula praestabit legumque silentia rumpet

e Calpúrnio por sua vez $(1,42-44)$ :

Aurea secura cum pace renascitur aetas et redit ad terras tandem squalore situque alma Themis posito

e o poeta do "Einsidlensis" $(2,23-24)$ :

Saturni rediere dies astreaque Virgo

tutaque in antiquos redierunt saecula mores.

Os dois poetas desenvolvem a idéia da fecundidade do mundo devida a Nero que reconduz os "Saturnia regna" e que é venerado pelas próprias árvores -(Calp., 4, 108-110). Em Calp. 1, deve-se notar o elogio da paz (v. 42; cf. v. 54,63 ); o poeta retoma o tema helennico do grande homem pacificador; assim os gregos haviam louvado Demétrio Poliorceta da paz restaurada. Qualquer que seja a bajulação dêstes poemas, o entusiasmo da época era real .... Sentimo-nos confundidos ao ver tāo continuamente Nero, deus "presente" (Calp., 4, 84), assimilado a Júpiter e a Apolo. Mas Sêneca dera o exemplo; nos v. 20 e ss. da "Apoc. 4. 1. correspondem os versos 9 e 10 de Calp. 4:

dulce quidem resonas nec te diuersus Apollo despicit, o iuuenis.

Mas os poetas ultrapassam ainda o tom de Sêneca ao identificarem Nero a Apolo ("Eins.". 1. 23-24) e a Júpiter (Calp.. 4. 142-143) (66).

Qualquer espécie de comentário seriá inútil, tāo evidente é a semelhança entre tais características $e$ as de que já tratamos no capitulo anterior; note-se, ainda, que "os temas da Idade de Ouro, da paz ou de um Império Apolíneo, utilizados por Calpúrnio, pelo autor das bucólicas do "Einsidlensis", por Lucano (66 A), encontram-se também nas tragédias de Sêneca (67), o que os confirma naa predileçāo da época.

\footnotetext{
(66). - Op. cit., págs. 228-229; cf. Amatucci, "La letteratura di Roma imperiale" pág. 60, em que o autor nota que apenas os temas são os mesmos de Virgilio, sendo bem diferente o espirito que os anima. A predileção por Virgílio foi tão intensa que justificou, para a época, o emprêgo da palavra "Maronolatria" (cr. Sikes, in "Canbridge Ancient History", XI, pág. 711).

(66 A). - "Farsalia", I.

(67). - Bardon, op. cit., pág. 240. O tema de Nero pacificador e retomado por Séneca, nas "Fenicias", v. 560.
} 
Incontestàvelmente, a personalidade que mais nos interessa dentro as que se destacam no panorama do periodo, tanto sob o ponto de vista político como cultural, é a de Sêneca, e julgamos ser de importância para o nosso estudo o destaque de três das idéias do filósofo-ministro; trata-se, aliás, de idéias que se mantêm dentro da linha da filosofia estóica.

Em primeiro lugar, devemos nos referir ao ideal do cosmopolitismo, de que "todos os homens sāo irmāos e solidários uns com os outros, que em lugar de fecharem-se nos estreitos limites de suas pequenas pátrias, devem considerar-se como cidadāos de uma grande pátria comum, que é o universo, que, longe de odiarem-se e de prejudicarem-se, devem amar-se e entreajudar-se (68)." Numerosas são as passagens que corroboram tais linhas; citemos, por exemplo, as seguintes:

"Dirijamos nossa vida segundo esta convicção: "Meu nascimento não me prende a um único recanto. $O$ universo inteiro é a minha pátria (69)."

"Dai a regra, da qual nos orgulhamos, não nos confinarmos nas muralhas de uma única cidade, mas de estabelecer relações com o mundo inteiro e de professar que nossa pátria é o universo... (70)."

"Não nos esqueçamos de que há duas repúblicas: uma, grande e verdadeiramente pública (71), abrange os deuses e os homens; ... outra, à qual nos prende o nosso do nascimento (Atenas. Cartago, ou não importa gual cidade)... (72)."

"Não farei caso de que a fortuna venha ou se distancie; olharei tôdas as terras como se fôssem minhas, e as minhas como se fôssem dos outros. E finalmente, viverei como quem sabe que nasceu para os outros; ... (73)."

Em segundo lugar, há o principio da igualdade entre todos os homens, tão revolucionário numa sociedade como a antiga (74), em que a escravidão era normal e encontrava o seu apôio em personálidade da envergadura da de Aristóteles, por exemplo. Nenhum trecho melhor do que o seguinte, para mostrar a maneira pela qual Sêneca considerava tal assunto:

"A natureza ordena-me auxiliar os homens; e se não escravos ou livres. nobres ou libertos, se gozam da liberdade como de um direito ou como de um presente de um amigo, o que importa? - Em todo o lugar em que há um homem, há oportunidade para se fazer o bem (75)."

(68). - Benoit, "Sêneque et Saint Paul", in "Revue Biblique", 1946, I, pág. 15: Glover, "The conflict of religions in the early Roman Empire", págs. 38, 63 ; Favre, "La morale des stoïciens", pág. 294 ; Westermarck, "Christianity and Morals", págs. 45, 108; Werner, "La Philosophie Grecque", págs. 232, 234.

(69). - Cartas a Lucilio, XXVIII, 4.

(70). - "De tranquillitate animi". IV, 4.

(71). - Isto 6 , "comum". "universal" (Waltz, nota 1 a pág. 116 da traducão).

(72). - "De Otio". IV, 1 .

(73). - "De vita beata", XX, 5 .

(74). - Revolucionário, é como Seneca é chamado por Pichon ("Hommes et choses de l'ancienne Rome", pág. 184).

(75). - "De vita beata". XXIV; cf. tanibém, por exemplo, a carta XI.VII, sobre os escravos. Cf. Westermarck, op. cit., págs. 284-285. 
A terceira idéia é relativa à Divina Providência, ou seja, à açāo constante da Divindade sôbre o mundo e à sua intervençāo nos negócios humanos. Não só os estóicos, mas também outras es. colas filosóficas a aceitaram; para nós, entretanto, o mais importante é que a escola predominante da Roma desta época foi a estóica, e que Sêneca, como seu maior representante, insistiu no tema da Providência (76). Leia-se, por exemplo, o "De Providentia", dedicado a Lucílio, e ter-se-á perfeita consciência dêste fato. Ora, nāo nos esqueçamos de que tais idéias constituiam ótimo apôio para as crenças já existentes da época de Augusto, de uma predestinaçāo de Roma, e que nāo poderiam senāo incrementá-las, contribuindo para uma exaltaçāo cada vez mais idealizada do papel da cidade na história.

E evidente que há uma linha continua de ideais, desde o fim da República até a época de que estamos tratando, linha esta que deveria ainda prolongar-se por algum tempo. Já pusemos em destaque a semelhança dos temas literários entre o periodo de Augusto e o dos primeiros tempos de Nero: retôrno da Idade do Ouro, com tôdas as suas principais características de prosperidade e de paz (77). E quer-nos parecer que isto só se explica em função da permanência das mesmas aspirações por parte do mundo mediterrâneo em geral.

Há, é verdade, um fato que poderia ser invocado e que abalaria, de certo modo, a nossa asserçāo; trata-se do seguinte: as idéias expressas por Sêneca, relativas à igualdade entre os homens, à solidariedade humana e ao univerșalismo, não eram grande novidade. uma vez que seus germens se encontram entre os estóicos antigos, sem que se possa falar ai na repercussāo imediata de uma grande aspiraçāo coletiva. Mas é fácil remover tal objeçāo; basta que se relembre o que tantas vêzes se tem dito a respeito do estoicismo romano em geral e do de Sêneca, em particular. Ao passo que o estoicismo helenístico era por demais frio e pouco humano, o romano afastava-se, de certo ponto de vista, do rigido sistema dos fundadores da escola, e em Sêneca, entāo, a filosofia estóica surgia numa forma muito mitigada, que fazia com que a orgulhosa auto-suficiência dos gregos do Pórtico cedesse lugar a uma sensaçāo de fraqueza e de imperfeiçāo (78). Provàvelmente, tal característica resultou do próprio senso prático dós romanos, que nunca tiveram o gôsto da especulaçāo pura, que pode dar ao. espírito o excessivo rigor lógico e uma espécie de fé ciumenta. Os estóicos

\footnotetext{
(76). - Aubertin, "Sénèque et Saint Paul", pág. 194; Glover, op. cit., págs. $38,59$.

(77). - Cr. Aubertin, op. cit., págs. 318-319.

(78). - Fisher, "The beginninge of Christianity", púg. 165; Orr, "Neglected factors in the study of the early progress of Christianity". pág. 181. Tudo isto, naturalmente, sem que deixasse de ser estóico; cf. Waltz, "Vie de Sénèue,", pág. 38.
} 
romanos, sobretudo, eram os menos sistemáticos de todos os moralistas e, de todos êles, o mais conciliante foi, sem dúvida alguma, Sêneca, que - vivendo no mundo, chegando a preceptor e a ministro de um Imperador - nāo podia fechar-se dentro de um sistema rigido e excessivamente impregnado de teoria da mesma forma como Diógenes se restringira ao seu tonel (79). Muito ao contrário, com êle, a frieza racional dos primeiros estóicos foi substituida "pelo calor de um coraçāo generoso", na expressāo de Benoit (80), o que o levou a emitir pensamentos confortantes, como êste: "A natureza... pôs em nós um amor mútuo e nos fêz sociáveis (81)." Parece-nos que o sentido humano que se reflete nesta frase autoriza-nos a dizer que, realmente, êle podia ser o porta voz das aspirações de seus contemporâneos em geral, e nāo apenas de um grupo ou de uma classe.

Ora, dissemos pouco acima que tais aspirações partiam do mundo mediterrâneo, e nāo só de Roma. Naturalmente, para dar justificativa a esta asserçāo, devemos procurar as grandes correntes do pensamento da segunda metade do século I, afim de verificar se sāo concordes nos ideais de solidariedade humana, de paz, de aboliçăo de fronteiras e de diferenças sociais. Já vimos o estoicismo, que dominava no mundo pagāo greco-romano; vejamos agora o que se passava com o sistema de crenças e de idéias que acabaria por absorver todo o Mediterrâneo antigo: o Cristianismo.

Em capitulo anterior tivemos ensejo de falar dos cristāos; mostrámo-los como adeptos de uma seita judaica, ligada aos israelitas no ódio ao Império Romano, ódio êste que se manifesta de maneira anacrônica na obra de Comodiano; apresentámo-los, em seguida, ligando-se a uma série de ideais relacionados diretamente com o Império e com a própria cidade de Roma, e destacamos a existência de um problema, que consistiria justamente na necessidade de se buscar uma explicaçāo para esta mudança de atitude. e que năo se fundamentasse em dados superficiais. Chegamos, agora, a êste ponto. Para nós, todo o grande alicerce desta reviravolta reside na concordância de idéias político-sociais, na época em que

(79). - Cf. Martha, "Les moralistes sous l'Empire Romain", pág. 11: "Mais, de tous les stoïciens, le plus conciliant est, sans contredit, Sénèque." Cf. Waltz, op. cit., pág. 39 .

(80). - Art. cit., pág. 16.

(81). - Cartas a Lucílio, XCV. 
se destacavam como expoentes máximos numa e noutra corrente, Sêneca e São Paulo (82).

Limitando-nos, evidentemente, apenas ao que interessa à nossa exposiçăo, podemos dizer que a grande importância de São Paulo reside em que a êle coube a revelaçāo de uma tendência já contida na própria origem do desenvolvimento das idéias cristās, a saber: várias destas idéias surgiram condicionadas pelas mesmas aspirações que determinaram, na esfera pagā, o impulso à expansão da crença no advento da ldade de Ouro, com tôdas as suas características.

Haveria, entāo, um grande ponto de convergência entre pagāos e cristāos, mas tal ponto nunca poderia ser posto em plena luz enquanto o Cristianismo se mantivesse preso ao Judaismo; e a Paulo coube a missāo, cuja importância ultrapassa em significado qualquer palavra que usássemos para qualificá-la, de efetuar o necessário desligamento. Julgamos que Wendland se expressa de maneira bastante justa e clara ao tratar do assunto, e será de real utilidade para nós servirmo-nos de suas palavras:

"Enquanto se pensava ser possivel poder traçar-se um quadro unitário do espírito antigo, lançando-se mão essencialmente, daqueles tempos, podia parecer que o Cristianismo entrara no mundo greco-romano como se fôsse uma fôrça de outro feitio e completamente extranha, e que sua história sòmente poderia ser compreendida sob o ponto de vista da luta e do domínio das resistências que se lhe opuzessem. Mas, o exame das correntes e disposições espirituais que dominavam a Antiguidade decadente, tem mostrado que esta época, compreendida na sua peculiaridade concreta, oferecia ao Cristianismo grande número de pontos de ligação e de intermediários, ia ao seu encontro com disposições e idéias aparentadas, de tal modo que a história do Cristianismo pode ser concebida dentro de um quadro de linhas concorrentes que convergiam no seu desenvolvimento."

"Na verdade, tal desenvolvimento nāo é tão inevitável como pode parecer evidente ao estudioso do passado, que pense poder compreender a lógica interna dos fatos por meio do seu têrmo final. A predicaçāo de Jesús apresenta dupla face, estando, de um lado, a ligaçāo com as imagens judias e o reconhecimento do vigor prático da Lei, e de outro, o seu esfôrço fundamental para a superaçāo dos limites nacionais (83). Contém ela em si, tanto a

(82). - Aubertin, op. cit., pág. 11: "De tous les apôtres, celui qui, par son genie naturel. par la grandeur de la mission qui lui fut confíe. par le nombre et le caractère de ses ecrits, exprime le plus parfaitement pour la postérité le spiritualisme chrétien, c'est Saint Paul, "cet homme du troisieme ciel (Bossuet)." De tout les contemporains des apotres, l'interprète le plus eloquent, le plus enthousiaste, sinon le plus irréprochable, de la morale stoïcienne, c'est Sénéque."

(83). - Cf. Wendland, "H.R.K.". págs. 220-230 e 231. 
possibilidade de sua reincorporação ao Judaísmo, como da vitória das tendên,ias universalistas que o impele para a frente. Na face voltada para traz, está a comunidade de Jerusalem, ao passo que a orientação para o futuro é definida por Paulo (84)".

Compreende-se, entāo, que da obra de Paulo dependeram a expansão e o sucesso da nova Fée, mas note-se, também, que houve mesmo antes dêle elementos que podemos chamar de precursores da independência do Cristianismo em relação ao Judaísmo. Jesús, naturalmente, estava ainda integrado na tradição judeu-palestiniana, e ainda que de seus princípios devessem sair uma religiāo e um sistema de idéias muito mais amplos do que o Judaísmo, seus primeiros adeptos eram reconhecidamente bons judeus (85). Intervém aqui, entretanto, um fato ao qual já tivemos oportunidade de fazer referência; trata-se da existência de duas espécies de judeus, a dos palestinianos e a dos emigrados, participantes da diáspora. Já vimos que os primeiros eram muito mais rígidos que os outros, e esta simples diferença, tornando possivel (pelo menos do ponto de vista da forma), a penetração de elementos culturais helênicos entre os membros da diáspora, abriu o caminho para a grande obra que deveria ser realizada por: Paulo (86). Na própria Jerusalem, em data anterior à da conversāo do apóstolo, distinguiam-se dois grupos entre os judeus que aceitaram o Cristianismo: um, abrangendo os que se apegavam ao Judaísmo, chamado dos "Hebreus", e outro cujos participantes foram designados pelo nome de "Helenistas" (87). De acôrdo com a interpretaçāo geralmente aceita., êstes últimos eram judeus que usavam a língua grega, por estarem, por si mesmos ou por seus pais, ligados à diáspora (88); eram peregrinos que vinham à cidade por ocasiāo das festas religiosas e dos quais alguns entravam na comunidade cristā (89). Por menor que fôsse a diferença entre os dois grupos, ainda que seu fundamento

(84). - Idem. idem, pág. 241: Guignebert, "La politique religieuse de Rome aux deux premiers siècles de l'Enpire", pág. 38.

(85). - Gilmour, "Paul and the primitive Church", in "Journal of Religion", vol. XXV, 2, pág. 119.

(86). - Paulo sempre iniciava as suas pregaçōes pelas sinagrogas: cf. "Atos", IX, 20; XIII, 5 e 14; XIV, 1; XVIII, 4, XXX, 8.

(87). - Tais designacōes encontram-se nos "Atos", 6, I" mas sem elucidação alguma quanto ao seu significado. Posteriormente seu sentido foi alterado, surgindo a palavra "Helenistas" entre os padres post-niceanos e em Juliano, como sinonimo de "pagãos". Cf. Goguel, "La naissance du Christianisme". pág. 190.

(88). - Esta é a interpretação dada por W. Bauer ("Griechischdeutsche Woerterbuch zu den Schriften des Neuen Testaments und der uebrigen urchristlichen Litteratur", Gie., 1828, s. v.) e F. Zorell ("Lexikon graecum Novi Testamenti"' 2, P., 1931, s. v.), ap. Goguel, "La naissance du Christianisme". pág. 190; cf. Goguel, "Les preniers temps de l'tiglise", pá 79 , em que o autor leva mais longe a diferença entre os dois grupos: "Le seul fait que les juifs ont eu a l'égard des Hellénistes une attitude toute différente de celle qu'ils avaient a l'égard des autres Chrétiens suffirait pour montrer qu'entre Hebreux et Hellénistes, il y avait autre chose qu'une différence de langue." Cf. Harnack, "Missione e propagazione", pág. 35.

(89). - Guignebert, "Le Christ", pág. 75, baseado em "Atos", 2, 5. 
fôsse de origem exclusivamente étnica (90), já seria grande a sua importância por prenunciar a amplitude que deveria logo ser assumida pelo movimento cristão, cujo sucesso dependeria do rompimento com o Judaísmo (91).

Aos Helenistas pertencia Estevāo, cujo discurso perante o Sinhédrio (92) presta-se a uma interpretaçāo bastante útil para o nosso trabalho: "Deus, teria êle pensado, desviou-se definitivamente de Israel e, daqui por diante, dirigir-se-á aos pagāos para constituir o Seu Reino. E tal modo de interpretar é confirmado pela atitude dos Helenistas que, em Antioquia, tomaram a iniciativa da pregação do Evangelho aos pagāos (93)." Ora, isto já significaria um violento golpe na concepçāo judia de "povo eleito", e contribuiria para orientar o Cristianismo num sentido universalista (94). E claro, entretanto, que tal orientaçāo só poderia ser decididamente precisada a partir do momento em que se firmasse a completa autonomia dos cristāos em relação ao Judaismo, o que foi realizado através da obra de Sāo Paulo.

Sob três aspectos nos interessa aqui a obra do apóstolo: o primeiro, relativo às suas relações com o Helenismo, o segundo, concernente ao seu rompimento com o Judaismo, e o terceiro, referente às suas idéias que pudessem ter reflexos no campo politico-social.

A própria origem de Paulo surge como um ponderável fator a ser considerado no tocante à sua atitude para com a Helenismo. Sem dúvida alguma, era êle judeu, e por duas vêzes o livro dos Atos apresenta-o confirmando tal asserção (95), sendo que numa delas, ao fazer sua defesa perante o povo de Jerusalem, assim se expressa:

"Sou judeu, nasci em Tarso da Cilícia mas criei-me nesta cidade, e instrui-me aos pés de Gamaliel conforme o rigor da Lei de nosso pais,

\footnotetext{
(90). - "Atos", VI, 9; cr. Lebreton, "L'Eglise primitive", pág. 139.

(91). - "Des deux, l'une est conservative d'instinct; l'autre va de l'avant: c'est elle qui a la vie et l'avenir. Et voila que, pour la première fois, se manifeste l'action fécondante de l'esprit grec" (Guignebert. "Le Christ", pág. 80; idem, pag. 127: "les Hellénistes commençaient à sortir du Judaisme, en considérant que les prescriptions cultuelles et les restrictions légales perdaient de leur valeur et de leur sens, dans la foi constituée autour du nom de Jesus-Christ. C'était comme un pré- paulinisme qui se levait là;..."). Cf. Lebreton, op. cit., pág. 143.

(92). - Cf. Fisher, "The beginnings of Christianity", pág. 473.

(93). - "Atos", II, 1921. Goguel, "La naissance du Christianisme", pag. 198; idem, "Les premiers temps de l'́́glise", pág. 82.

(94). - O próprio discurso de Estevão é um violento ataque aos judeus, como se vé nos "Atos". VII, 51-53. Cf. Moffatt, "An introduction to the Literature of the New Testament", pág. 201; Goguel, "La seconde génération chrétienne", in "Revue de l'Histoire des Religions", tomo CXXXVI, n. ${ }^{\circ}$., pág. 39: "Partout et toujours, depuis le temps d'etienne, le judaïsme s'est montré résolument hostile à toutes les formes du christianisme qui, comme la pensee d'Etienne et des Hellénistes et, plus tard, le Paulinisme, étaient entachees d'antilégalisme et d'antiritualisme et orientéses vers l'universalisme."

(95). - IX, 11; XXI, 39; XXII, 3: Cf. Guignebert, "Le Christ", pag. 218 e ss.. em que o autor põe em dúvida a veracidade desta asserção, mas com o prévio cuidado de dizer ser impossivel provar-se que ela é falsa. Westermarck, "Christianity and Morals", pág. 106.
} 
sendo zeloso para com Deus, assim como todos vós os sois no dia de hoie ..."

E aí evidente, nāo só a sua situaçāo de judeu, mas também o caráter israelita de sua educaçāo, orientada por "um fariseu chamado Gamaliel, doutor da Lei, acatado por todo o povo (96)." $O$ que é também interessante, tanto nesta como em outras passagens, é a referência à cidade de origem de Paulo, "Tarso, cidade nāo insignificante da Cilícia (97)", em que êle teria recebido sua primeira educação, grega quanto à forma e quanto à lingua, de tal modo que mesmo a Biblia de que se servia e a qual citava, era a grega, a versāo dos setenta, e nāo o Antigo Testamento hebraico (98), o que já seria u'a maneira pela qual poderiam ter-lhe sido proporcionados contactos com idéias gregas. Compreende-se tal fato ao se verificar a posiçāo de Tarso no panorama cultural da época do nascimento de Paulo, quando se sabe que a localidade atingia, entāo, o seu ponto mais brilhante, sendo considerada como uma das três grandes cidades intelectuais do Mediterrâneo Oriental e que, sequndo Estrabāo, estava em condições de competir com Atenas e Alexandria (99). O mesmo autor (100) enumera os eruditos, filósofos, gramáticos e retores que lá viviam e entre êles destacando-se os estóicos Antipater, Arquedemus, Nestor e os dois Atenodoros, um dos quais foi tāo ligado a Augusto. A fama que tais personagens conquistaram até na própria cidade de Roma dá bem idéia do ambiente de cultura em que foi criado o futuro apóstolo. Sim, porque apesar de ser judeu e de ser grande a colônia judia em Tarso, é claro que se tratava de elementos da diáspora, tocados pelo Helenismo, o que determinou mesmo a predominância do grego no aspecto externo da formaçāo de Saulo, nada menos impossivel de se ter realisado do que a hipótese de ter o jovem judeu conhecido e ouvido alguns dos expoentes intelectuais da época na sua cidade natal, como por exemplo. Nestor, cuja escola

\footnotetext{
(96). - “Atos". V. 34

(97). - "Atos", XXI. 39. De acôrdo com uma tradição transmitida por são Jerónimo ("De Viris", 5; "Ad Philem." 23), Paulo teria nascido em Gischala, na Galiléja; hoje em dia, entretanto, Tarso é aceito pelos eruditos como a indubitável pátria do apústolo. Cf. Guignebert, "Le Christ", pág. 213; Nock, "St. Paul", pág. 21; Finagan, "Light from the arcient past", págs. 253-255.

(98). - Volmer, "Die altiestamentlichen Citate bei Paulus", pág. 103, ap. Goguel, "La naissance du Christianisme", pág. 234; Wendland, "H.R.K.", págs. 243,356 (bem entendido, Wendland não opina pelos contactos es. treitos com o Helenismo, - ao contrário de outros que chegam a vêr em São Paulo um clássico de Helenismo (Norden, "Antike Kunstprosa', I, págs. 500 e ss., ap. Goguel, op. cit., pág. 234); cf. págs. 244 e 356); Guignebert, "Le Christ", págs. 220, 240; idem, "Le Christianisme Antique", pág. 87; Puech, "Histoire de la littérature grecque chretienne", I, pág. 182.

(99) . - Cf. Guignebert, "Le Christ", pág. 221 e ss.; jdem, "Le Christianisme Antique", pág. 85; Nock, op. cit., pág. 22 ; Gilmour, art. cit., pág. 126 ; Prat. "La théologie de Saint Paul", I, pás. 16; Noger, "Les religions révélées". II, pág. 210.

(100). - XIV; V, 13, 14, 15.
} 
floresceu neste periodo (101). Mesmo se consultarmos os autores menos inclinados à admissão de contactos entre Saulo e o Helenismo, vamos acabar por encontrá-los cedendo, ainda que com restrições, diante da realidade, isto $\dot{e}$, diante da evidência de que era quase impossivel um isolamento completo em relaçāo ao ambiente helenizado de Tarso (102). Veremos que Aubertin, por exemplo, após afirmar que nem a educaçāo pagā nem a alexandrina foram dadas ao apóstolo na sua juventude, mas exclusivamente a educação judia e os ensinamentos da sinagoga; que seria um absurdo supor-se que seu pai o houvesse confiado a mestres pagãos ou alexandrinos, para depois enviá-lo a Jerusalem, onde a ciência grega era detestada e onde os mestres alexandrinos eram expulsos da sinagoga, acaba por encontrar-se diante do seguinte problema: entāo, a permanência de Saulo em Tarso foi sem influência sôbre o seu espirito? - $A$ isto Aubertin responde pelo mínimo possivel, dizendo que o futuro apóstolo teria ai aprendido o grego (103), encaminhando-se depois para outra explicaçāo dos contactos entre Paulo e o Helenismo. Após aventar e afastar êle próprio a hipótese de que o gôsto pela ciência grega lhe tivesse sido inoculado pela escola de Gamaliel (que recebera a excepcional permissão de cultivar a filosofia pagã), assim se expressa o autor em questāo: "Eis, enfim, uma suposiçāo mais legítima. Paulo, após a sua conversāo, que teve lugar no ano 34 , refugiou-se em Tarso, fazendo aí uma estadia de alguns meses, ou mesmo de um ano. Lá, nāo só converteu êle a sua família, mas, liberto dos precon-

(101). - Vigouroux, art. "Tarse", in "Dictionnaire de la J3ible"; Stock, art. "Stoics", in "A Dictionnary of the Bible"; Wendland, H. 'R. K.", pág. $24 \pm$; Puech, op. cit., I, pá.g. 317: "Bien que Paul n'eat pas reçu la haute culture grecque, et que, s'il a passé par l'école du grammatiste, il n'ait pas connu celle du rhéteur ou du philologue, il ne peut avoir manqué d'entendre, à Tarse, dès sa jeunesse, et, plus tard, à Antioche ou ailleurs, quelques cyniques ou quelques stoïciens itinérants..." Cf. Guignebert, "Le Christ", pág. 224.

(102). - Cf. Stählin, in Christ, "Geschichte der griechischen Literatur", II, pág. 11.34: "Tarsos war damals ein Mittelpunkt hellenischer Bildung, und wenn Paulus auch gewiss keine der Grammatiker - oder IRhetorenschulen seiner Vaterstadt besuchte, so konnte or sich doch dem Einfluss des inn umflutenden grieclischen Lebens nicht entziehen." Cf. Puech, op. sit., I, pag. 179; Guignebert, "Le Christ", pág. 241: "Un Juif? - As surément; mais un Juif de la Diaspora ét elevé par elle dans son plopre esprit, deja contamine largement par l'hellénisme." Fischer, "The beginnings of Christianity", pag. 478: "Tarsus was a cultivated city, and a seat of philosophical study. It is much more probable that Paul acquired his knowledge as he had, of Greek thought, from personal intercourse with those in whose company he would be cast, than from the study of the Greek authors."

(103). - Ainda que nada mais houvesse do que isto, não poderiamos dizer que se tratava de pouca cousa. Pelo menos, assim se expressa Prat, ao se referir ao assunto: "Du milieu nous tenons le langage, ce merveilleux instrument de l'activité mentale, lassociation inconsciente et lo tour habituel de nos pensées, avec un patrimoine plus ou moins riche de concepts élaborés pendant des générations avant de nous échoir en héritage" ("La théologie de Saint Paul, I, págs. 14-15). Cf. Guignebert, "Le Christ", pag. 234: "Ce serait tout, comme on l'a soutenu. que ce sarait deja beaucoup, car non seulement la connaissance du grec lui a fourni un incomparable moyen d'action, mais, par elle-méme, elle a fajt entrer en lui quelque chose de l'esprit et de l'ame de l'hellënisme ambiant." 
ceitos do Judaísmo, pôde conversar mais livremente com os gentios, observar mais de perto suas opinióes e seus costumes, discutir com os filósofos, como fêz mais tarde em Atenas, preparando-se assim para a missāo que lhe estava reservada. Nāo experimentamos repugnância alguma por êste parecer (104)." De qualquer maneira, mesmo dizendo depois que, em Sāo Paulo, ."o elemento profano é nulo e que o elemento religioso é tudo (105)", Aubertin nāo pode negar a existência de contactos entre o apóstolo e o mundo helenistico. Há, entretanto, um fato a estranhart no que nos diz o referido autor: como se explica que Paulo, fariseu, filho de fariseus, repentinamente, imediatamente após à conversāo, tivesse passado a interessar-se pelo Helenismo, ao ponto de ir a Tarso para discutir com filósofos e aprender o necessário dos sistemas filosóficos afim de ficar preparado para sua missāo? - Por que a conversāo implicaria em aproximaçāo com os gentios, e por que haveria margem para empregar-se, logo após a conversāo, a frase "liberto dos preconceitos do Judaísmo", se admitimos que a formaçāo de Saulo foi orientada apenas pela sabedoria judia e pelos ensinamentos da sinagoga? - Muito mais razoável, ainda mais, digno de todo o apôio, parece-nos um dos mais recentes historiadores do Cristianismo ao ressaltar que, "judeu da diáspora e fariseu, Paulo, se bem que imbuido da idéia da eleiçāo de Israel, ficou alheio às preocupaçóes politicas" e que, "nascido e criado no mundo grego, o problema do mundo pagão impôs-se à sua consciência e deu ao seu pensamento uma amplidāo à qual devia corresponder a sua concepçāo do Cristianismo como religiāo universal (106)." A tais conclusões, pensamos, nāo poderiamos chegar pelo caminho traçado por Aubertin, e sāo elas, entretanto, que parecem estar de acôrdo com o próprio desenvolvimento da missāo do apóstolo.

Quer-nos parecer, assim, que podemos lançar mäo de dois fatos para que se possa explicar a atitude de Paulo após a conversāo:

1 - Ainda que judeu não pôde êle escapar às influências do ambiente helenistico em que se formou:

2 - Afastando-se das preocupações politicas do Judaismo, desinteressando-se da restauração da independência nacional e do triunfo final de Israel. estava éle preparado para dar um sentido universalista ao Cristianismo e para ter uma série de aspirações decorrentcs dêste grande fato, como por exemplo, ao cosmopolitismo e à paz, que o aproximariam dos ideais dos estóicos na sua época (107).

\footnotetext{
(104). - Aubertin, "Séneque et Saint-Paul", pág. 2\$-33.

(105). - Idem, Idem, pág. 34 .

(106). - Goguel, "La naissance du Christianisme", pág. 235; nf. "Les premiers

(107). - Hé mesmo quen explique a conversão de saulo atralés da predominancia do estoicismo no meio em que ele se formou, cumn se ve: "It is of particular. interest to note that a famous philosophar. Athenodorus ( 74 B. C. - A. D. 7), who had influenced considerably the thought
} 
$\mathrm{E}$, diante disto, até mesmo a questāo dos contactos com o Helenismo passa para um segundo plano, - bem entendido, dentro da linha do nosso trabalho, - uma vez que aspirações comuns em certo setor, num mesmo momento, devem ser produzidas por causas semelhantes e levam, naturalmente, à aproximação as corren'tes em que se manifestem. A tendência de Paulo a chegar-se aos gregos acha-se, a nosso ver, decidida fundamentalmente pelo seu desinterêsse em relaçāo às questões politicas, o que the permitiu levar avante uma das grandes caracteristicas básicas do Cristianismo primitivo, conforme vimos acima: o esfôrço para a superação dos limites nacionais. Neste caso, mesmo independentemente de qualquer formaçāo grega, haveria base para a expansão do Cristianismo entre os elementos mediterrâneos de cultura helênica, em virtude da semelhança de várias aspirações (108). Neste sentido interpretamos nós a "plenitudo temporum", que seria o momento em que predominassem de maneira tão precisa certos sentimentos comuns a todo o mundo antigo, que deveriam encontrar-se nas mais fortes correntes do pensamento, encaminhando-as para a aproximaçāo recíproca, fôsse qual fôsse a sua origem (109). Só isto pode explicar que, por mais distintas que se apresentassem o Evangelho e a doutrina estóica (110), concordassem elas numa série de principios (111), que houvesse entre êles uma tal conformidade de máximas, de acôrdo tāo freqüente de sentimentos, a tal ponto que se tornasse possivel o lançamento da hipótese segundo a qual a causa de tudo isto seriam empréstimos feitos pelos filósofos aos ensinamentos sagrados (112).

of Seneca, had lived in Tarsus very near the time of wlich we are speaking, and whose teaching was undoubtedly influential in the univerșity of Tarsus after his death. There is reason to believe that Paul was brought up in a society which was permeated by Stoicism. It is not improbable that his conversion, as has been found to be the case with other religious conversions, was connected with a previous preparation for it in his own mind in the form of a subconscious incuhation which, when ripe, burst into flower" (Westermarck, "Christianity and Morals", pág. 107).

(108). - "Das Gefuhl der Schuld und Schwäche. Sehnsucht nach Erlösung und göttlichem Beistand, Verlangen nach Offenbarungen, willige Hingabo an Autoritaten haben wir als vorherrschende Stimmungen des untergehe ndes Altertums kennen gelernt" (Wendland, "H. R. I.", pág. 236; cf. págs. 238-9).

"Entre lui (le Christianisme) et la réligiosité antique il existe comme une harmonie préetablie: le drame du Calvaire offre un point d'appui historique a toutes les aspirations diffuses de l'ame paienne" (Simon, "Verus Israël", pág. 441). Cf. Boissier, "La religion romaine", II, págs. 397 e ss..

(109). - Cf. Wendland, "H.R.K.", pag. 228; Barth. "Los Istoicos"; pág. 282.

(110). - Sobre tais diferenças, cf. Wendland, "H.R.K.", pág. 232.

(111). - "IEntre l'école du Portique et l'Evangile il existe des différences essentielles; mais quelque distinctes et séparées que soient ces doctrines, un trait leur est commun: toutes les deux s'accordent a faire prédominer l'âme sur le corps. l'esprit sur la matière, à prècher le détachement des choses perissables, le gout des biens surnaturels, l'exercice des plus austères vertus". (Aubertin, op. cit., pág. 5). Cf. Showerman, "Eternal Rome", págs. 297-298.

(112). - Aubertin, op. cit., pág. 10; Boissier, "La religion romaine". II, pág. 378; Barth, op. cit.. pág. 284. 
Entre os ideais comuns, o da igualdade de todos os homens parece-nos dos mais importantes. Já o vimos com os estóicos, pará os quais "todos os homens são irmãos". Em São Paulo manifesta-se idéia semelhante, como se pode ver, por exemplo, no discurso pronunciado em Atenas: Deus "fêz, de um mesmo sangue, tôdas as nações de homens para que habitassem sôbre tôda a face da terra (113)", e "não pode haver judeu nem grego, nem escravo. nem homem livre, nem homem nem mulher, pois todos vós sois um em Jesús Cristo (114)". Nota-se entāo, inicialmente, a idéia da divisāo da humanidade em dois grandes grupos, o dos judeus e o dos gregos, ou melhor, dos circuncisos e incircuncisos; e em seguida a de que ambos devem ser acolhidos na Igreja de Cristo, de tal modo que, numa unidade superior, cessem tôdas as diferenças fundamentais entre êles (115). "O povo cristāo, para Paulo, nāo é um terceiro ao lado de outros dois; é uma nova fase da história humana que se encaminha para o supremo fim, que deverá suceder à velha fase da humanidade dividida em duas partes, suprimindo e tornando vāo nāo só as diferenças nacionais e politicas, mas também as sociais e, por fim, as diferenças de sexo (116)." Ora, já vimos antes que os estóicos tinham êste mesmo fim em vista (117). sendo de se destacar ainda um outro traço de aproximaçāo entre êles e os cristãos: para êstes, o caráter "democrático-cosmopolita" foi, sem dúvida, um valiosissimo elemento auxiliar da propaganda entre as classes médias e inferiores, sobretudo nas provincias, uma vez que é claro que a igualdade religiosa tinha, até certo ponto, um significado político-social (118); para aquêles, também influiu uma causa semelhante na facilidade de expansāo entre os mesmos elementos sociais, porquanto, decde o periodo helenístico a sua atividade propagadora orientara-se para a massa do povo, uma vez que êste era realmente o campo apropriado para a divulgaçāo de

(113). - "Atos", XYII, 26; Cf. I Cor. XII, 12-25, Magnin. "L'état, conception paienne, conception chrétienne, pág. 30-31; Nock, "St. Paul", págs. $27-2 S$.

(114). - "Gralatas", III, 2s; cf. "I Coríntios", XII, 13; "Colossences", III, 11 ; "Romanos", V, 12; idem, III, 29; "IEfesos", III, 6. Cf. Brunner, "Der Apostel Paulus". in "Universitas", janeiro de 1951. pág. 15: Westermarck, op. cit., pág. 105; Wendland, "H. R. K.", pág. 231; Tơnnbee, op. cit. TI, pág. 11. A propósito desta passagen diz Bréhjer o semuinte: "Saint Paul est un hellene d'éducation et. soit. influence directe, soit action difuse de doctrines partout repandues, on trouve chez lui nombre d'idées. de manières de penser. d'expressions familières a séneque et surtout à spictète. Le christianisme comme le stoïcisme est cosmopolite; et il ne connait qu'une vertu commune à tous les etres raisonnables. "Point de Juif, ni de Grec, d'esclave ni d'homme libre, de sexs masculin ou féminin ; tous vous etes un en Jesus-Christ." Comme la diatribe stoicienne, saint Paul prêche la parfaite indifference au point de vue du salut, de la condition sociale dans laquelle on vit" (op. cit., I, pág. 49:5).

(115). - Coulanges. "IAa cité antique", pág. 460; Magnin, L'śtat, pág. 20 e ss.. (110). - Harnack, op. cit.., pág. 186; ce. Wendland, "H.R.W."., p气g. 43.

(117). - "Dem höchsten religiösen Massstabe gegentiber sind" die Unterschiede der Nation. des Standes, des Geschlechtes indifferent. Dieser Standpunkt berührt sich mit den hellenistischen, besonders stoischen Gedanken der Humanität, der allgemeinen Menschenwurde und der gemeinsamen Menschenrechte" (Wendland, "H. R. K.", pág. 231.)

(118). - Harnack, op. cit., pág. 187, nota 2. 
uma filosofia que pregava a nivelaçāo da sociedade, procurando dirigir-se para as verdades éticas fundamentais e para os problemas da vida prática (119). Tal traço que, aliás, fôra levado a alto grau de desenvolvimento pelos cínicos (120), foi de enorme importância, o que justifica a maneira pela qual Wendland o considerou, situando-o no panorama geral da História. Principiando por destacar que êste tipo de propaganda filosófica nāo atraira a atenção dos historiadores da Filosofia - que se interessaram mais pelo desenvolviniento dos diversos sistemas - o referido autor continua dizendo que, entretanto, isto nāo quer dizer que o fato deva ser posto de lado, como se fôsse insignificante para a História. Muito pelo contrário: agindo mais pela palavra oral do que pela escrita, tal atividade podia orientar-se para a massa da população, muito realizando em favor da educaçāo moral do povo e do reconhecimento em larga escala de certos conceitos morais fundamentais. Nestas condições, muito antes que os predicadores cristãos levassem ao mundo a nova mensagem, predicadores pagāos trilharam caminho semelhante, procurando também espalhar entre os homens uma nova mensagem. Nos horrores e na confusão dos primeiros tempos helenisticos, numa sociedade que surgia das ruinas do passado para uma nova vida, atormentada pelos abalos da transiçāo e pelas incertezas do futuro, encontraram os cinicos em primeiro lugar o frutífero ambiente para o desenvolvimento de sua missāo. Tais pregadores sentiam-se como se fôssem encarregados de elevada tarefa, e foram continuados através de todo o periodo helenístico e romano, para chegar ao seu maior florescimento durante o Império, quando o mundo antigo viu-se em condições semelhantes às dos primeiros tempos helenísticos (121). Tudo isto, naturalmente, preparou grande parte da populaçāo para a recepçāo do Cristianismo (122), e compreende-se, diante do exposto, que

\footnotetext{
(119). - Wendland, "F.JR.K.", pág. 75; Moore, "The decay of nationalism under the Roman Empire", in "Transactions and proceedings of the American Philological Association", vol. XIJIII, piig. 34.

(120). - Cf. Villeneuve, "Issai sur Perse", pag. 119 e ss. : I3ardy, "La conversion au Christianisme durant les premiers siecles", pág. 83-\$4.

(121). - Wendland, "H.R.K.", págs. 81-82.

(122). - Idem, pág. 91. Cf. Uberweg, "Crundriss der Geschichte der Philosopbie", I, pág. 409: "Mündliche Predigt und literarischer Traktat schufen philosophischen Gedanken und Ueberzeugungen weiteste Verbreitung. So wurde de Philosophie zu einer gewaltigen Macht im Leben der alten Völker und behauptete sich als solche auch tiber die Antike hinaus unter der Herrschaft des Christentums, dessen Emporkommen und Ausbreitung sie durch hohe ethische Anforderungen, durch Wachhaltung religiösen Sinnes und durch ihre Mitwirkung an ciner universellen Kultur gefördert hatte und an dessen dognatischer Ausgesta.ltung sie in hervorragender Weise beteiligt war." Cf. Goguel, "I'neumatisme et eschatologie," I, pag. 130. Sobre a diatribe cínico-estoica, veja-se também Guignebert, "Le Christ", págs. 160 e ss., de onde destacamos a-seguinte passagem: "Ia prédication cynico-stoïcienne offrira au christianisme un cadre ethique et un vocabulaire; elle iui menagera aussi une passerelle pour pénétrer au plein de la vie pratique du monde hellenistique ... Il $y$ a donc la une viritalle preparation de I'action chritienne, dans les diverses directions qui s'imposeront à elle a mesure qu'elle s'affermira: une próparation tellement efficace qu'on ne conçoit pas que le christianisme ait pu s'en passer, qu'il ait pu être si elle n'avait eté" (pág. 163).
} 
tenhamos dito que a questāo de se saber se Paulo teve ou nāo grandes contactos com a cultura grega antes de sua conversāo passa para um segundo plano, - repetimos - dentro do nosso tema. E claro que era muito natural que os cristāos, quando começaram sua penetração na esfera helenistica, fôssem de certa maneira influenciados por esta predicaçāo pagā, devendo-se ainda notar que, antes que tomassem contacto com as grandes obras da literatura antiga, os cristāos conheceram os elementos filosóficos que já se haviam tornado populares em virtude da propaganda a que nos referimos; a própria forma desta propaganda, aliás, pôde exercer, assim, certa influência sôbre a literatura epistolar do Novo Testamento (123). E podemos dai inferir que muitas destas idéias tivessem servido de base para facilitar a predicaçăo, desempenhando - papel de ponte pela qual os cristãos pudessem penetrar na massa popular do mundo antigo; mesmo a atitude de Paulo em Atenas (124) seria de molde a fazer com que o apóstolo se apresentasse de maneira semelhante à dos filósofos populares, tanto a forma e os hábitos da predicação popular pagà passavam a ser postas a serviço das missões cristās (125)'.

Levando-se em conta a clara tendência de aproximação com os pagāos de cultura grega, caberia ainda qualquer dúvida a respeito de qual poderia ser a atitude de Paulo em relaçāo aos cristāos que persistiam em continuar ligados ao Judaísmo, ou - numa palavra - aos judeu-cristặos? A êste mesmo Judaismo que contava com uma velha tradiçāo de resistência aos gregos, que fazia com que os israelitas se considerassem um povo superior aos demais, nāo abdicando em parte alguma de suas caracteristicas básicas, formando um grupo à parte em qualquer cidade grega ou romana em que vivessem, e que já profetizara a queda de todo o mundo pagăo para que Israel pudesse surgir em tôda a sua glória?

(123), - Wendland, "H.R.K.", págs. 91, 356-357; cf. Moffatt, "An Introduction to the literature of the New Testament.", pag. 46. Devemos notar, 6 verdade, que não é fácil, atualmente, "faire le départ entre les procédés instinctifs de la prédication populaire et les procédés cyniques qui, par la seconde sophistique, sont passés dans la prédication chrétienne" (Lejay, "Les Satires d'Horace", pág. XIII e nota 2, ap. Villeneuve. "Essai sur Perse", pá.g. 132. nota 1) ; Cr. Nock. "St. Paul," pág. 23ñ. O material para a comparação foi reunido por $R$. Bultmann, "Der Stil der paulinischen Predigt und die kynisch-stoische Diatribe". “Forschungen zur Rel. und Lit. des A. und N. T.", XiII Goett., 1910 (ap. Wendland, "H.R.K.", pág. 356, nota 4).

(124). - A respeito do discurso do Areópago um dos mais importantes trabalhos at $e^{\circ}$ he publicado foi o de Norden, "Agnostos Theos. Untersuchungen zur Formengeschichte religiöser Rede"; so a pudemos conhecer, entretanto, atraves da crítica de Lagrange, publicada na "Revue Biblique". tomo XI, págs. 442 e ss., 1914. Achamos útil transcrever aqui as seguintes linhas de Lagrange, a pág. 448 da referida revista "Ce n'est rien moins que la recontre du iudaïsme avec la philosophie socratico-stoïcienne, de la religion la plus haute de l'antiquité avec la philosophie la plus noble, au service de l'idée chrétienne....

Concluons simplement que Paul connaissait mieux la philosophie qu'on ne le pensait avant la démonstration de M. Norden," Cf. Barth,

(125). - Wendland, "H.R.K.", pág. 246; Cf. Stock, art. "Stoics", in "A Dictionary of the Bible"'. 
$\mathrm{E}$ ainda mais, que desde os tempos de Estevāo mostrava-se resolutamente hostil a qualquer forma de Cristianismo que se revelasse anti-legalista e anti-ritualista, orientando-se para o universalismo (126)? E evidente que nāo se pode hesitar a êste respeito, mesmo porque já nāo se tratava da pessoa de Paulo, mas de duas tendências que a fôrça das cousas tinha determinado no Cristianismo, desde que começara a trilhar terra helênica. De acôrdo com a primeira, uma vez que o Mestre quizera permanecer estritamente no plano do Judaismo, seus discipulos, transformados em seus apóstolos, não tinham razão para dai sair, permanecendo presos à perspetiva da esperança messiânica judia; a segunda tendência decorre justamente do transporte de sua esperança para o terreno grego, o que precipitou a evolução de sua fé e fêz dela uma religião verdadeira que em breve nāo mais se preocupou com o Judaismo e seus adeptos, chegando Paulo, por fim, a proposições doutrinais que repeliam a Lei como inútil, dado que, se ela merecesse ainda a atribuição de algum valor salutar, seria necessário acreditar que - Cristo Jesús morrera por nada (127).

O conflito entre Paulo e o Judeu-Cristianismo era, entāo, inevitável; de fato, durante tôda a sua carreira, sobretudo a partir de 44, esteve o apóstolo em luta, tanto com o Judaismo, como com o Judeu-Cristianismo de Jerusalém (128), sempre apegado à

(126). - Goguel, "La seconđe génération chrétienne". pág. 39.

(127). - "Galatas", III, 11; "Romanos", II, 17 e ss.: "Mas se tu és chamado judeu, e repousas na lei, e te glorias em Deus, e conheces a sua vontade, e aprovas as cousas excelentes, sendo instruido na Lei, e estás persuadido que tu és guia dos cégos, luz daqueles que estão em trevas, instrutor dos ignorantes, mestre das creanças, tendo na Lei a fórma da ciência e da verdade; tu, pois, que ensinas a outro, não te ensinas a ti mesmo? - Tu que pregas que não se deve furtar, furtas? - Tu que dizes que não se deve cometer adultério, o cometes? - Tu que abominas idolos, roubas os templos? - Tu que te glorias na Lei, desonras a Deus pela tua transgressão da Lei? - Pois é por vossa causa que o nome de Deus é blasf́emado entre os Gentios, como está escrito." Idem, VII, 6: "...; mas agora desligados estamos da Lei, por termos morrido para aquilo em que estavamos presos, de sorte que sirvamos em novidade de espirito e não na velhice da letra." Cf. Guignebert, "Le Christ", págs. 285-287; idem, pág. 240: "Assurément, sa vocation chrétienne a signifié pour lui la rupture avec son passé juif e d'aucuns soutiennent même qu'il était devenu incapable de comprendre et d'apprécier le pharisaïsme qu'il avait dépouillé, quand il écrivait une vingtaine d'années après;..." Simon, "Verus Israël", pág. 97; Brunner, "Der Apostel Paulus", pág. 18.

(128). - "I Tess." II, 15. Cf. Graetz, "A History of the Jews", II, pág. 229 e ss. ; Glover, "The conflict of religions in the early Roman Empire". pág. 169: "That part of the Jewish race, and it was the larger part, which did not accept the new religion, was in no mind to admit either Paul's premisses or his conclusions. They stood for God's covenant with Israel. Nor did they stand alone, for it took time to convince even Christian Jews that the old dispensation had yielded to a new one, and that the day of Moses was past. To the one class the rise of the Christian community was a menace, to the other a problem. The one left no means untried to check it. By argument, by appeals to the past, by working on his superstitions, they sought to make the Christian convert into a Jew; and, when they failed, they had other methods in reserve. Themselves every where despised and hated, as they are still, for their ability and their foreign air, they stirred up their heathen neighbours against the new race. Again and again, in the "Acts" and in later documents, we read of the Jews being the authors of pagan persecution (justin, Trypho, c. 17; Tert., adv. Jud., 
Lei. Entre as epistolas, as duas dirigidas aos corintios e a destinada áos gálatas são particularmente ilustrativas a êste respeito. Já dissemos que, antes de Paulo, houvera elementos favoráveis à ruptura do horizonte estritamente judeu do Cristianismo, tanto que foram expulsos de Jerusalém e fundaram em Antioquia uma Igreja própria, que foi visitada por Paulo após a sua estadia em Tarso, depois de sua conversāo (129). Mas Faulo, ao contrário dêstes, deu ao universalismo um fundamento dogmático que o levou a encarar como atitude eqüivalente ao próprio abandôno do Evangelho qualquer tentativa para conduzir os pagāos convertidos a observâncias, rituais que os ligassem ao quadro de Judaísmo (130). Daî a oposição que encontrou êle por parte dos elementos judaisantes, dispostos a todo o custo a perturbar o seu esfôrço apostólico, e que eram dirigídos pela İgreja de Jerusalém. Dentro da diáspora, no interior das sinagogas às quais Paulo se dirigia para pregar o Evangelho, deviam encontrar-se alguns conversos que o seguissem, mas haveria sempre aquêles que, seguindo a tendência predominante entre os judeus, estavam dispostos a defender até o fim o seu patrimônio de tradições, indo - quando muito - à consideraçāo do Cristianismo como uma seita judaica, comparável às já existentes, v. g. a dos Fariseus, a dos Saduceus e dos Essênios (131) .

Desde o início de sua missāo sofreu o apóstolo ataques por parte dos judeus, que pretenderam tirar-lhe a vida em Damasco, motivo pelo qual teve que fugir, indo para Jerusalém e, depois, para Tarso (132). Ainda os judeus continuaram a perturbá-lo nas suas viagens evangélicas, constituindo-se no grande obstáculo a tôda a primeira parte de sua carreira (133). Em seguida, quando abandonou as sinagogas para dirigir-se às "Igrejas domésticas" ou a qualquer lugar julgado conveniente para a pregaçāo. Paulo sempre encontrou pela frente a resistência do Judeu-Cristianismo. Episódios dêste conflito foram o chamado "concilio de Jerusalém" (134) e a desavença de Antioquia (135). após a qual teve Paulo

\footnotetext{
13). The "unbelieving Jew" was a spiritual and a social danger to the Christian in every city of the Last. The converted Jew was, in his way, almost as great a difficulty within the community." Cf. pag. 171. Harnack, op. cit., pag. 34.

(129). - "Atos". XI, 20 e ss.

(130). - Goguel, "La naissance du Christianisme", pág. 320.

(131). - Aliás, é como tal que o Cristianismo aparece mencionado em presença dos judeus e do sumo sacerdote Ananias. durante a acusação feita a Paulo; nada mais ê do que "a seita dos Nazarenos" ("Atos", XXIV, 5).

(1.32). - "Atos", IX, 23 e ss.; posteriormente, sũo freqüentes os ataques, como se vê em "Atos", XIII, 45; XIV, 2 e 19; XVII, 5, XVIIJ, 6.

(133). - Guignebert, "Le Christ", pâg. 284.

(134). - "Atos", XV, 1-33; "Gálatas", II, 1 e ss.. Cr. Guignebert, "Le Christ" págs. 286 e 304; Goguel, "La naissance du Christianisme", pág. 323 e ss..

(135). - "Gálatas", II, 11 e ss.. Cf. Lebreton, "L'tíglise Primitive", pág. 169: Goguel, "Les premiers temps de l'óglise, pág. 87; idem, "La naissance du Christianisme", pag. 329 e ss.; Fisher, "The beginninge of Christianity", págs. 485-486; Guignebert, "Le Christ", págs. 30i-308.
} 
que lutar contra a propaganda judaisante até mesmo nas Igrejas por êle fundadas, na Grécia e na Galácia. Um primeiro traço desta luta deixa-se perceber na epistola aos Felipenses (136), a "crise de Corinto" pode ser considerada um seu episódio (137), e ela surge em tôda a sua plenitude na epístola aos Gálatas (138). dirigida àquêles que de tal modo haviam sofrido a açāo judaisante, que estavam a ponto de abandonar o Evangelho pelo Judaísmo (139). A combatividade revelada nesta epístola dá bem idéia da agudeza do conflito entre o apóstolo e os judeus e judaisantes, e explica a advertencia que the foi feita pelo profeta Agabo em Cesaréia, a caminho de Jerusalém, no momento em que se devia. iniciar nova fase de sua atividade missionária (140). De fato, percebia êle claramente os perigos a que se expunha indo a Jerusalém, uma vez que os judeus tomariam tal gesto como uma verdadeira provocaçāo; ao mesmo tempo, nāo havia nen mesmo a menor garantia de boa acolhida por parte da Igreja local. O conhecimento ¿ desta situação, aliás, externa-se na epistola aos Romanos (141).

$\mathrm{Na}$ realidade, sabe-se o que aconteceu em seguida: o motim popular, a prisāo de Paulo pelo tribuno romano e o início do processo que deveria levá-lo ao suplício. Durante todo êste tempo, conforme nota Goguel (142), nāo só a Igreja de Jerusalém nāo foi molestada pelos judeus (o que mostra que ela não era solidária com Paulo), mas ainda mais, a propaganda judaisante continuou e talvez tenha mesmo conseguido dominar a própria Igreja de Roma, o que poderia explicar a indiferença por esta demonstrada em relação ao apóstolo, nada fazendo em seu favor durante o seu cativeiro. Conclui-se entāo, à vista do exposto, que não houve apenas divergências, mas hostilidade entre Paulo e os judeus e cristāos judaisantes (143), e que esta situaçāo foi gerada pelas tendencias universalistas do primeiro, que nāo se conformava com a manutenção do Cristianismo nos quadros estreitos de uma

(136). - I, 12-18. Cf. Goguel, "La naissance du Christianisme", pág. 331.

(137). - Goguel, "La naissance du Christianisme", pág. 340.

(138). - Cf. Moffatt, op. cit., pág. $\$ 3$ e ss.; McNeile. "Introduction to the New Testament", pág. 129 e ss.; Nock, "St. Paul", pág. 161 e ss..

(139) - Cf. Goguel, "Les premiers temps de l't́glise", pág. 1.07 e ss..

(140). - "Atos", XXI, 10 e ss. Goguel, "Pneumatisme et eschatologie", in "Revue de l'histoire des religions", CXXXIII, Janeiro-Junho, 1947-1948, pas. 119, nota 2.

(141). - XV, 30-32; Cf. Goguel, "La naissance du christianisme", pág. 344.

(142). - "La naissance đu christianisme", pág. 346; idem, "La seconde génération chrétienne", pág. 42.

(143). - Talvez seja útil lémbrar-se aqui a existência da famosa passagem da epistola aos Romanos, a respeito da qual disse Harnack que era o trecho do Novo Testamento mais altamente marcado pelo Judeu-Cristianismo ("Dogmengeschichte", I, pág. 318). Ora, inclinamo-nos mais para o ponto de vista de Goguel, que assim se manifesta a respeito: "Le ton de profonde émotion sur lequel est écrit ce morceau, montre qu'il faut $y$ voir autre chose qu'une page de philosophie de l'histoire. C'est une réponse $a$ une accusation qui a atteint Paul dans les fibres les plus profondes de son coeur, celle d'etre l'ennemi du peuple d'Israël et de méconnaitre l'election particulière dont il avait été l'objet". ("La naissance du christianisme", pág. 345). 
seita judaica; "Paulo, o fariseu, destronou na História o povo e a religiāo de Israel; êle tirou o Evangelho do terreno hebraico e transplantou-o para o terreno da humanidade (144)." E nada menos inviável do que a existência de uma relaçāo entre a obra do apóstolo e a sua qualidade de cidadāo romano, que fazia com que, para êle. o conceito de oix ou $\mu$ év romana tivesse realmente sentido, um sentido que deveria ter contribuido para determinar no seu espirito a idéia da unidade específica da raça humana, cujo corolário era o universalismo da religiāo de Cristo (145).

Nesta mesma época, como vimos, Sêneca expunha certos ideais que revelavam grande semelhança com alguns dos princípios de Sāo Paulo. Quererá isto significar que, obrigatòriamente, tivesse havido alguma espécie de contacto entre o filósofo e os cristāos, para nāo falarmos em relaçāo com o próprio apóstolo? - Já dissemos que não, e repetimo-lo agora, servindo-nos das palavras de Martha: "Sāo Paulo não depende mais dos mestres de. Sêneca do que Sêneca de São Paulo. Houve no mundo, nesta época, duas correntes semelhantes, de energia e de pureza bem desiguais, uma vinda do Oriente e outra do Ocidente, que se encontraram sem misturar-se, que se opuzeram antes de.fundir-se. Desde longo tempo as mesmas idéias morais amadureciam em tôdas as partes do Império Romano, e de progresso em progresso a filosofia, sem o saber, ia ao encontro da nova lei. Assim se fazem sempre no mundo as revoluções morais; para que se realizem, é preciso que sejam preparadas (146)".

Não deixa de ser interessante, entretanto, que se tenha desenvolvido a lenda da correspondência entre o filósofo e o apóstolo e que tenham mesmo surgido as cartas entre ambos trocadas, nas quais se observam passagens como a seguinte, por exemplo, atribuida a Sêneca:

"Eu te saúdo, meu caro. Paulo. Se tu quiseres, sublime apóstolo da caridade, não só unir completamente teu nome ao meu, mas não ser

\footnotetext{
(144). - Harnack, op. cit., pág. 41. Em nota a esta passagem, o autor chama a atença para o fato de que, mais tarde, os judeus chegaram a sustentar que Paulo não passaria de um pagão disfarçado. Cf. Goguel, "La naissance du Christianisme", pág. 222: "IEn montrant dans le christianisme l'accomplissement de la promesse faite à Abraham, il a definitivement lie - et cela dans la méme esprit que Jésus - le christianisme a la religion des patriarches, de Moìse et des prophetes, tandis que, par l'iaee que le Christ avait mis fin au règne de la Loi, il réalisait la religion universelle qui etait en germe dans l'śvangile." Gilmour, "Paul and the primitive church", pág. 127: "It was Paul who made it impossible for Christianity to continue as a constituent part of Judaism. It was Paul who forced the church to emerge from its Semitic chrysalis. It was paul who transformed Christianity from a Jewish sect into a world religion'".

(145). - Guignebert, "Le Christ", pág. 242; Cf. Wendland, "H. R. K.", pág. 244 : Festugière, "Liberté et civilisation chez les Grecs", pág. 92: "Saint Paul est fier dappartenir a la cite de Tarse; il argue de son titre de citoyen romain. S'il déclare, sans doute, que "notre vraie cité est dans les cieux" (Philipp., 3, 21), c'est pour rappeler la fin dernière: il ne vise aucunement a renverser l'ordre terrestre."

(146). - Martha, "Les moralistes sous l'Empire Romain", pág. III.
} 
senão uma úunica pessoa comigo. isto será uma grande honra para o teu caro Sêneca. Tu és o cimo, o mais elevado pico entre tôdas as sumidades ... (147)."

A isto teria Paulo respondido da seguinte maneira:

“Tuas pesquisas profundas encontraram verdades que a Divindade revela apenas a alguns homens. Semeio então, tranqüilo, um campo daqui por diante fertil, uma semente vigorosa, que nem é material, nem está sujeita a corromper-se; é o Verbo imutável, einanação de um Deus, que cresce e que permanece eternamente. A sabedoria conquistada pelo teu gênio não deve desfalecer. Evita, acredita-me, as objeções dos pagãos e dos iudeus. Tornar-te-ás um novo autor, consagrando à glória de Jesús Cristo um talento irrepreensivel (148)".

A questão da autenticidade destas cartas deu origem a uma série de pesquisas cujo resultado foi, para uns, positivo, e para outros, negativo. Fleury (149), por exemplo, esforçou-se para provar a legitimidade, mas em seguida, a publicaçāo da obra de Aubertin e a parte consagrada ao assunto por Boissier (150), praticamente liquidaram a questāo, de maneira contrária à autenticidade. Tratar-se-ia, então, de cartas apócrifas, forjadas no decorrer do século IV (151).

Ora, para nós, pouco importa que tais epistolas tenham sido legitimas ou nāo; o fato de existirem já significa muito, e é mesmo suficiente para que se possa chegar, pelo menos, a uma conclusāo: a da certeza da existência de afinidades entre estóicos e cristāos paulinianos, senāo em todos os setores (o que seria um absurdo e nāo nos passaria pela mente afirmar), ao menos de maneira parcial e justamente no dominio que interessa ao nosso tema. Evidentemente, se fôsse possivel provar-se a autenticidade das cartas, nāo poderia ser negada a relaçāo entre as duas correntes; mas, mesmo assentada a falsificaçāo, demonstra-se a enorme afinidade entre elas. Porque é claro que a idéia de forjar tais epístolas nāo teria surgido ao seu autor se nāo se houvesse sentido desde muito a semelhança de certas idéias entre o estóico e o apóstolo (152); esta verificaçāo justificaria de tal maneira a existência de uma troca de cartas, que estas viriam a ser aceitas até mesmo por São

(147). - Carta XI, ap. Aubertin, op. cit., in Apêndice.

(148). - Idem, Carta XIV.

(149). - "Saint Paul et Sénèque: recherches sur les rapports du philosophe avec l'apotre, et sur l'infiltration du christianisme naissant à travers le paganisme." Paris, Ladrange, 1853, 2 vols..

(150) . - "La Religion romaine", II, pág. 47 e ss.; Cf. Hochart, "Istudes sur la vie de Sénéque", pág. 40.

(151). - De acórdo com Barlow ("Ipistolae Senecas ad Paulus et Pauli ad Senecam quae uocantur", in "Papers and Monographs of the American Acad, in Rome', vol. 'X, 1938;' págs. 89-92, ap. Bardon, op. cit., pág. 255, nota 3), tais cartas foram compostas antes de 392 , por muitos estudantes em competição, o que explicaria suas incoeréncias e contradições.

(152). - Cf. Wendland, “H.R.K.", pág. 94; Martha, op. cit., págs. 13, 70-71; Amatucci, "La letteratura di Roma imperiale", pág. 59; Labriolle, "La reaction pairenne", pág. 27. 
Jerônimo, que incluiu a Sêneca no "De Viris", entre os autores cristāos (153). Nāo interessa, portanto, que se trate de falsificaçāo; na realidade, o ponto de partida para um entendimento entre os cristāos e o mundo antigo parece residir na época em que deveria ter sido trocada aquela correspondência, se ela fôsse legitima (154). Nāo interessa, também que a aparência dos fatos continuasse a demonstrar a existência de um conflito entre o Império $e$ os cristāos, mesmo porque os elementos básicos para o acôrdo, isto é, o estoicismo e o paulinismo, nāo tiveram imediatamente um periodo de tal sucesso que evidenciasse a fôrça de seus ideais.

Em relaçāo a Paulo, o que se pode dizer é que, "desde o conflito de Antioquia, sua situaçāo foi piorando constantemente. Sentiu-se cada vez mais isolado, mal compreendido, mesmo nas Igrejas por êle fundadas, por tôda parte encontrou o obstáculo de uma viva oposiçāo fomentada por elementos adversos. Após um longo cativeiro do qual, após a de Jerusalém, a Igreja de Roma desinteressou-se, morreu êle, enfim, talvez sem que a Igreja o tenha sabido. Poderia parecer que, com Paulo, era a própria causa do universalismo que desaparecia e que, desviando-se dêle, a Igreja estava condenada a permanecer presa aos quadros do Judaísmo, a nada mais poder ser do que uma seita judaica (155)."

Quanto aos estóicos, sabe-se perfeitamente o fim que teve Sêneca, a oposiçāo feita pelos filósofos aos Césares (156) e a atitude dos Flávios a seu respeito, mormente Domiciano, que os expulsou de Roma (157), na época em que, no Epiro, Epiteto suportou o exilio como um verdadeiro discipulo da Estoa, que em tôda a parte se achava em sua pátria e que se considerava como um legítimo cidadāo do mundo (158).

Tudo isto, entretanto, nāo impediu que o afastamento dos cristāos em rèlaçāo ao Judaísmo se processasse, nem que a seme-

\footnotetext{
(153). - "De Yiris", XII. Santo Agostinho, por sua vez, admitiu a autenticidade da correspondência entre Sêneca e São Paulo ("De Civitate Dei", VI, 10); Cr. Hochart, "studes sur la vie de Sénèque". págs. 39.

(154). - Bardon, op. cit., pág. 255; Friedläinder, "La Sociedad Romana", pág. 1117.

(155). - Goguel. "La naissance du Christianisme", pág. 347; "I’neumatisme et Eschatologie". II, pág. 13i, unde se lê que sú nas proximidades do ano 90 foi feita a reunião de tỏdas as epístolas de Paulo. Reflexos do abandóno em que se viu o apóstolo durante o seu cativeiro podem ser encontrados em "II Timóteo". J, 15; IV, \& e ss.; cf. Fouard. "Saint Paul, ses dernières années". phí. $27 \%$.

(156). - Cf. Boissier. "L'opposition sous les César's", págs. 103 e ss.: Bardon. op. cit., págs. 250, 301-302, 330; Martha, op. cit., pag. 79; Waltz. "Vie de Sénèque". pág. 43: Rostovtzefe. "Historia social $y$ económica del Imperio Romano". T, págs. 22S. 233; Bréhier, op. cit.. J. pá.g. 420 ; Charlesworth, in "Cambridge Ancient History"; XT, pág. 9: Brunschvicg, "Le progrệs de la conscience dans la philosophie occidentale". I, pág. 61: Dudley, op. cit., pá.g. 128 e ss.: Wendland. "H.R.K.". pág. 44: "Und in der Kaiserzeit konnte die stoische Tuehre zur Begrüdung des römischen Weltreiches verwendet. aber auch. da wieder die kynischen, weltabgewandten Tendenzen hervordringen, die Unterlage für einen unfruchtbaren oppositionellen Doktrinarismus oder frondierende Gesinnung hergeben."

(157). - Suetónio, "Domiciano", X: Tácito, "Agricola". II.
}

(158). - Martha, op. cit., pág. '195, nota 1. 
Thança de ética entre Paulo e a filosofia que estivera ligada às próprias origens do regime imperial lançasse as bases para uma aproximação entre o Império e os cristāos, dentro das grandes linhas do universalismo e do cosmopolitismo.

Observemos entāo, partindo do que dissemos acima, a marcha de cristāos e pagãos para um mesmo ponto, constituido pela idealizaçāo de Roma e de seu papel no plano da História.

No lado pagāo verifica-se cada vez mais a importância assumida pela filosofia do Pórtico, que nos apresenta o seu mais rigoroso e conseqüente representante na pessoa de Epiteto. Escravo êle próprio, estava bem em condições de dirigir-se ao elemento baixo da população, continuando a linha de propaganda dos cinico-estóicos (159); para alcançar o seu objetivo, servia-se o filósofo de um estilo simples, de linguagem popular, empregando comparações tiradas do espetáculo da vida cotidiana, revelando certa originalidade plebéia que nāo hesita em lançar māo de expressões vulgares, tomadas à via pública, contanto que ficasse mais accessivel aos que o ouviam (160). E continuamos a encontrar sempre a concepçāo do Universo como uma grande comunidade:

"Este Universo é uma república, e a substância da qual êle foi feito é também única: e há na sua economia uma inevitável periodicidade que faz com que as cousas dêm lugar umas às outras - uma cousa desaparecendo enquanto outra passa a existir, e algumas permanecendo inamoviveis enquanto outras estão em movimento. E tudo é abundante em amigos: em primeiro lugar os deuses, mas também os sêres humanos, que são igualmente amigos naturais porque foram designados pela natureza para viver como membros de uma familia humana (161)".

(159). - Empregamos a expressão cinico-estoicos em virtude do parentesco e das aproximacões que existiam entre as duas escolas. Cf. Dudley, op. cit., pags. $137,154-155,187-199$, em que merece ser transcrito o seguinte trecho, referente aos séculos I e II de nossa era: "Throughout this period, then, Cynicism was a kind of radical Stoicism: the relation between the two may be likened to that between the nore ascetic monastic orders and the main body of the Catholic Church" (pág. 199). Bardy. "La conversion au christianisme durant les premiers siècles", pág. 58: "Le cynisme tel que l'enseigne et le pratique Dion Chrysostome, s'apparente etroitement au stoïcieme, et à la fin du Ier siècle après J.-C. il y a lonetemps en effet que les deux doctrines se sont fait des emprunts mutuels, de telle sorte qu'il est presque impossible de les distinger l'une de l'autre." Caster, "Lucien et la pensée religieuse de son temps", págs. 12-13: "Le stofcisme s'était distingue du cynisme - d'où il etait sorti, - par son travail scientifique. Celui-ci passant au deuxiême plan, le rond aynique réapparaissait." A semelhança entre os adeptos das duas escolas fazia-se sentir até no as pecto exterior: "Le stoicien prenait volontiers l'uniforme de sa secte: cheveux ras, barbe longue et manteau simple: tenue cynique adoucie" (pág. 15). Idem, páss. 65 e ss.; Murray, "Stoic, Christian and Humanist", pág. 57.

(160). - Martha. op. cit... píg. 197.

(161). - "Dissertationes", III, 24; Cf. Toynbee, op. cit., VI, pág. 333. 
Mais expressivo ainda, por revelar o profundo desprèzo pela política naquilo que ela possa apresentar de pequeno e de particularista, e por evidenciar que o legitimo objetivo do espírito bem formado é a comunidade e nāo o particularismo, é o seguinte trecho do mesmo filósofo:

"Suponho que você quer perguntar-se se o sábio cínico imiscuirse-á na politica? - 0 estúpido! Que maior campo de atividade política propõe você a êle, do que o campo no qual êle está realmente trabaIhando? Deve êle estabelecer-se em Atenas e fazer um discurso a respeito de rendas ou de abastecimentos, quando o seu papel é dirigir-se a todo o mundo - Atenas e Corinto e Roma num mesmo auditório mundial - e ter como assunto, não abastecimento ou rendas, ou paz ou guerra, mas a prosperidade e a adversidade da alma, a boa e a má fortuna, a escravidão e a liberdade? - Você vê um homem trabalhando em um campo de atividade politica daquela envergadura, e me pergunta se êle deve imiscuir-se em politica?" (162).

Tais idéias tornam-se ainda mais interessantes para nós quando as aproximamos do que acima dissemos a respeito do desinterêsse de São Paulo pela política, o que teria sido um dos grandes motivos do seu afastamento do Judaismo. E nada mais fàcilmente digno de ser subscrito por um cristāo do que um trecho como êste que, ligado ao fato de que os estóicos desde a origem de sua escola interessavam-se pela vida pública, só pode conduzir a uma conclusāo: a de que, neste setor, a missão mais digna era a de agir junto aos governantes, ao mesmo tempo que junto ao povo, para conseguir que a autoridade pública cada vez mais pudesse ter sucesso no escopo de elevar o padrāo moral da massa da populaçāo, dando muito maior importância à "prosperidade e à adversidade da alma, à boa e a má fortuna, à escravidāo e à liberdade", do que a mesquinhos assuntos de limitadissimo interêsse, aos quais sempre estava alheio o que de melhor pudesse haver no espírito humano, relacionados apenas com "rendas ou abastecimentos" de Atenas, Corinto ou Roma. Mesmo porque,' de maneira semelhante à de Cícero, Epiteto vê razões profundas para que se acabe com as idéias particularistas:

"Se há verdade no que dizem os filósofos a respeito do parentesco entre Deus e os homens, não resulta dai a moral, para nós, homens, de que se deve fazer como Sócrates e nunca dizer, quando perguntada a nacionalidade de alguém, que se trata de um ateniense ou de um corintiano, mas sempre responder que é um natural do Universo? - Por que você se chama a si próprio de ateniense, em lugar de chamar-se simplesmente pelo nome do canto no qual aconteceu que, ao nascer, fôsse depositado o seu desprezivel corpo? - Não é óbvio que você se chama a si mesmo um ateniense ou um corintiano porque a área que é indicada pelos nomes de Atenas ou de Corinto é intrinsecamente mais importante $e$ ao mesmo tempo compreende não só o canto no qual você 
realmente nasceu, mas também o coniunto de sua casa e, enfim, as raizes da árvore de sua familia? - Bem, qualquer um que tenha estudado a cconomia do Universo, terá aprendido que a maior, mais impcrtante e. mais vasta de tôdas as cousas é êste sistema de Deus e homens, e terá também apreendido que Deus foi a fonte da vida não sommente para meu pai e meu avô, mas para tudo que vem à luz e cresce sôbre a superficie da terra, particularmente para creaturas dotadas de Razão, desde que só estas são capazes de gozar de um verdadeiro intercânbio com Deus, graças aos laços pelos quais a Razão os liga a Ele" (163).

Com Epiteto entramos em plena época dos Antoninos, periodo de apogeu da filosofia militante e que, por feliz coincidência, teve para contribuir ao sucesso de seu advento o tipo do filósofo popular, do pregador impenitente, que foi o cínico Diāo Crisóstomo (164), e terminou - na realidade - com o reinado de Marco Aurélio, o mais completo exemplo do filósofo-imperador. $E$ aqui notamos pela última vez o aparecimento de um estóico ilustre, o derradeiro de nomeada, a revelar-se também favorável à mesma idéia de cosmopolitismo. de colaboração entre os homens (165), após o govêrno excepcionalmente pacífico de Antonino-o-Pio, o que traz sempre à mente a ligaçāo Estoicismo-Paz-Cosmopolitismo-Igualdade entre os homens. Leia-se, por exemplo, o seguinte trecho:

"Se a inteligência nos é comum, a razão, que faz de nós sêres racionais. nos é comum. Admitido isto, é também comum a nós esta razão cujo papel é o de prescrever o que se deve ou não fazer. Admitido isto, a lei também nos é comum. Isto admitido, nós somos concidadãos. Isto admitido, nós fazemos parte de um mesmo corpo politico comum. Admitido isto, o mundo é como uma cidade" (166).

Coloca-se assim. Marco Aurélio, na mesma linha estóica que inspirara Cícero e que devia remontar, pelo menos, ao século II a. C. (167). Várias outras passagens (168) revelam os ideais do cosmopolitismo, mostram grandes semelhanças com trechos de Epiteto, e de Sêneca, evidenciando sempre a persistência das mesmas

(163). - Idem, I, 9; cf. II, 9. Cf. Toynbee, op. cit., pág. 335-336; Ueberweg, op. cit., I, pag. 497.

(164). - Cf. Rostovtzeff. "Historia social y economica del Imperio Romano". I, pags. 227 e ss. : Martha, op. cit., pags. 293 e ss.: Dudley. op. cit., pags. 140-141. 148 e ss..

(165). - "Pensamentos", II, 1. Cf. Trannoy, trad. "Pensées", págs. X-XI. o Estoicismo áliás - diga-se de passagem - domina tóda a época imperial ou, pelo menos, até os Scveros; of. Weber, "Kulturgeschichte als Kultursoziologie", pág. 163: "Der Stoizismus .... ist die repräsentative Philosophie dar Kaiserepoche."

(160). - "Pensamentos". IV, 4. Cf. Trannoy, op. cit., págs. VIJI-IX; Werner, "La Philosophie Grecque", pags. 232, 234.

(167). - Farquharson, "The meditations of the Imperor Marcus Aurelius Antoninus", pág. 311: o mesmo autor, entretanto não deixa de dizer que. em principio, pode-se conduzir tais idélas até muito antes do estoicismo médio, ou seja, até Heráclito de refeso.

(168). - III, 1I: X, 15; XII, 1. Cf. os comentários de Farquharson, op. cit., : Ueberweg, op. cit., I, pág. 501. 
aspirações por parte da elite do mundo romano (169). E evidente que nāo se pode negar que muitas das idéias de Marco Aurélio, bem como de seus predecessores, revestiam-se de um caráter completamente místico, por assim dizer; tanto que a parte final do livro IV dos "Pensamentos" é o "argumento de que a existência da cidade eterna, assim estabelecida pela razāo, é a prova de que a razão do homem deriva da que governa e inspira a Cidade de Deus (170); além disso no livro II, sob um ponto de vista mais profundo, o imperador sugere a Cidade do Universo ("Civitas Dei" de Santo Agostinho, "Reino dos Fins", de Kant). Ele lera muito bem a história do passado para imaginar que mesmo a grande potência mundial, que êle governava, durasse além da hora que lhe fôra estabelecida. A Cidade de Deus, da qual êle pensa aqui, é eterna, fundada no céu (171)." Mas, por outro lado, nāo podemos negar, também, que a simples leitura da obra realizada por Marco Aurélio durante os seus dezenove anos de govêrno levará à conclusão de que êle estava longe de ser um utopista (172), tanto que se apiedava dêstes "pobres políticos que pretendem tratar os negócios públicos segundo as máximas da filosofia", assim se expressando: "sāo verdadeiras crianças... Nāo esperes que haja em tempo algum uma república de Platāo; contenta-te em fazer com que as cousas avancem um pouco, e năo olhes como sendo sem importân,cia nem mesmo o menor progresso" (173).

$E$, dentro das possibilidades, Roma não tinha dado um passo, - maior que se poderia esperar, no sentido da realizaçāo terrena do grande ideal de república do Universo? - Nāo teria chegado o mais pròximamente possivel àquêle ideal estóico, segundo o qual tôdas as diferenças de raça, credo, condiçāo social (174), desapareceriam sob o poder da razão, que capacitaria os homens a viverem em igual comunhāo, uns com os outros, e todos com os deuses?

$\mathrm{Na}$ realidade, de certo ponto de vista, o Império Romano representava, para os pensadores contemporâneos, êste reino da justa lei (175), e Marco Aurélio tinha conciência disto, o que, certamente, te-lo-ia levado a escrever que "o fim das criaturas dotađas de razāo é êste: obedecer às regras e decretos da mais venerável de tôdas as cidades e govêrnos" (176). Roma, entāo, continuava a ser objeto de verdadeira idealizaçāo, iniciada desde a

(169). - A época dos Antoninos, aliás, abriu-se em meio a um cansaço de guerras e de desordens, o que gerava novas aspirações a um período de calma e de prosperidade. Cf. Tácito, "Historias", I, 2.

(170) . - Farquharson, op. cit.. pág. 310 .

(171). - Farquharson, op. cit.. pág. 295-296.

(172). - Cf. Puech, prefácio "Pensées", pág. III.

(173). - "Pensamentos", IX, 29; V, 17. Cf. Puech, prefácio aos "Pensées",

págs. XIX-XX.

(174). - Cf. Wendland, "H.R.K.", pag. 43.

(175). - Farquharson, op. cit., pág. 295.

(176). - "Pensamentos", II, 16; cf. VI, 44 e IX, 12. Aristides, "A Roma", 65. 
época de Augusto, e que a apresentava como uma entidade benéfica por excelência, mantenedora da paz e da ordem, única fôrça terrena capaz de manter ligados numa grande organizaçāo tantos povos diferentes, sempre beneficiados pelo seu dominio. Era a extensão a todo o Império do culto da Dea Roma, exaltada pelos literatos, celebrada pelos artistas, que triunfava em uma esplên.dida apoteose no afresco que ornava o grandioso templo consagrado a Venus e a Roma, iniciado por Adriano e terminado por Antonino-o-Pio (177).

Isto, aliás, já condicionara, em 144, talvez o mais famoso de todos os elogios feitos à cidade: a oraçāo "A Roma", do retor Elio Aristides, cuja importância é tāo grandemente encarecida por Rostovtzeff (178). Escrevendo em 144, em pleno fastigio da Pax Romana, Aristides podia exclamar que "Todo o mundo civilisado depôs o pêso das armas, seu antigo fardo, e passou a embelezar-se e a gozar as alegrias da paz" (179), dando a entender que, de fato, correspondiam à realidade as inscrições "Pax Augusta", "Felicitas Imperii", "Securitas publica", "Tranquillitas Imperii", "Tellus Stabilita", "Pax Aurea", "Saeculum Aureum", encontradas continuamente nas moedas de Adriano e de Antonino-o-Pio (180). Graças a esta paz podia haver no Império a prosperidade produzida por um trabalho tranqüilo e profícuo, que se expressava pela intensidade do comércio, da navegaçāo, da agricultura, da mineraçāo, enfim, de tôdas as atividades humanas pordutivas (181), espetáculo êste que justificava as palavras do orador:

"Aquêle proverbial modo de se dizer: "a terra é mãe de todos, pátria comum a todos", foi por vós exibido no seu verdadeiro valor.

(177). - Cf. Homo, "Le siècle d'or de l'Empire Romain", pág. 338-339; idem, "La civilisation romaine", pág. 174; Gagé, "Recherches sur les jeux séculaires", pégs. 101-102.

(178). - "Historia social y económica del Imperio Romano", I págs. 261 e ss. cf. Toynbee, op. cit., VI, págs. 343-344; idem, "Civilisation on trial", pág. 256: "If any human community were ever worthy of worship, it would be a universal state, like the Roman Empire, that has brought the blessings of unity and peace to a world long racked by war and revolution."

(179). - "A Roma", 97 ; cf. 69-70. Sôbre a oração de Aristides, cf. Rostovtseff. "Historia social y económica del Imperio Romano", I, pág. 261 e ss. : Weber, in "Cambridge Ancient History", XI, pág. 316.

(180). - Stella, "In Gloria di Roma", págs. 42, 54 e 127; Gage, "Recherches sur les jeux séculaires'. pág. 111. As infrações à paz que então se verificassem não eram tidas como atingindo nem o principio e nem a realidade da paz romana: cf. Homo. "La civilisation romaine", pág. 121: "on les considere comme des occidente temporaires ou locaux, sans plus, qui ne menacent en rien l'oeuvre de la civilisation romaine et ne compromettent a aucun titre son avenir." F'estugiere, "Liberté et civilisation chez les Grecs", pág. 101: "De quelque façon qu'il se soit établi, l'Empire romain n'a subsisté, en tant des provinces et pendant tant de siecles, que parce qu'il était une garantie de paix: Tax Romana!" o mesmo autor insiste sôbre o assunto, afirmando que nåo foi a fôrça das armas a responsável pela duração do impé-

1) rio: "Les faibles garnisons qu'elle (Rome) maintenait dans les pro-

1) rio: "Les faibles garnisons qu'elle (Rome) maintenait dans les proavaient conçu vraiment le dessein de se révolter"' (pág. 102). Cf. Aristides, op. cit.
Romana", pág. 16-17. 
Hoje é possivel, tanto ao heleno como ao bárbaro, viajarem fàcilmente em qualquer direção, com ou sem os seus haveres, como se passassem de uma pátria a outra. Não mais metem medo as portas da Cilicia e as estreitas passagens através do deserto arábico para o Egito, nem montes inaccessiveis, nem amplidões demarcadas por rios, nem tribos inóspitas de bárbaros: parạ passar incólume por tôda a parte basta ser romano, antes, basta pertencer ao vosso império."

"O dito homérico: "a terra é comum a todos", graças a vós é hoje una realidade. Vós medistes tôda a terra habitada, lançastes pontes de todo o gênero para ligar as margens opostas dos rios, talhastes os flancos dos montes para abrir estradas carroçáveis, enchestes as regiōes desertas de estações de abastecimento; civilizastes o mundo levando a ordem por tôda a parte, bem como um mais alto teor de vida".

"Antes de vosso govêrno, penso, a vida devia ser análoga à vida antes de Triptolemo; dura, selvagem, não muito diversa da que se leva sôbre as montanhas...: pusestes todo $\circ$ mundo em ordem sob as mesmas leis, pusestes fim a todos os usos anteriores, divertidos de se narrar, mas sôbre os quais é intolerável discorrer-se. Removestes todos os obstáculos às núpcias, enquadrastes o mundo todo numa única organização, como uma só familia" (182).

Perfeitamente lógico, pois, que uma potência à qual o mundo era devedor de tantos beneficios, devesse durar eternamente, para felicidade dos homens; em virtude disto podia o retor dizer que "mais unânime do que um côro, todo o mundo civilizado levanta, a uma só voz, a invocaçāo para que o vosso império dure eternamente" (183), para adiante terminar a sua peça com o mesmo tema:

"Invoquemos todos os deuses e os filhos dos deuses, afim de que concedam à Urbe e ao Império prosperidade eterna, perene, sem fim..." (184).

Nota-se por estas passagens que, na época dos Antoninos estavam ainda em plena efervescência os mesmos ideais do periodo de Augusto: a paz, o universalismo, e a eternidade de Roma, como realizadora dêstes sonhos, como entidade benfeitora dos homens. Já vimos que, por meio de Sêneca e de seus contemporâneos, tais idéias não haviam desaparecido durante o periodo intermediário, graças ao desenvolvimento da filosofia estóica, que foi

(182). - Idem, 100-102; cf. 30: “Por tôda a parte todos são governados pelas mesmas leis'. Aqui, certamente, o autor refere-se às reformas de Adriano, de unificacãa das leis imperiais; sob o governo dêste imperador, na medida das possibilidades, ter-se-ia realizado um grande passo para a aplicação prática da concepçũo universalista do Istado, que jă vimos ser täo importante nas jdéias cínico-estóicas (cf. Stella, op. cit., págs. 28, 39, 61). Cf. Courcelle, "ITistoire littéraire des grandes invasions germaniques", pág. 8 .

(183). - "A Roma", 29; cf. Stella, op. cit., pág. 32. Cf. Toynbee. "Civilisation on trial", pág. 177: "IEmpires... which bestow peace for centuries on once war ridden worlds, win so powerful a hold on the affections and imaginations of their subjects that there cannot imagine living without them, and, consequently, cannot believe that these supposedly indispensable institutions can ever really cease to exist."

(184). - Idem. 109. A respeito da prosperidade do Império neste periodo, veja-se Gibbon, op. cit., cap. I. 
justamente a grande inspiradora da politica dos Antoninos (185). Aliás, tais imperadores, como Antonino-o-Pio, por exemplo, podiam ser considerados como encarnações do ideal estóico do "ótimo principe", cuja posição seria devida às qualidades que dêles fariam os melhores dentre os cidadāos de seu tempo (186). Estoicismo e idealização de Roma estavam assim ligados estreitamente, a cidade surgindo como máxima concretizaçăo possivel dos ideais daquela filosofia, a tal ponto que um retor, como Aristides, que nada tinha de filosofo, era levado - talvez sem nisto pensar a desenvolver temas caros ao estoicismo. E achamos tal fato muito significativo, muito mais do que se a referida oração tivesse sido composta por alguma personalidade conhecida pelas suas tendências filosóficas; isto porque, se nela nāo sāo enunciadas teorias de escolas filosóficas nem de grupos políticos, sendo apenas descrita a realidade de uma época (187), e apesar disto são encontrados trechos coerentes com idéias antes expressas por um cinico, como Diāo de Prusa, ou por estóico, como Sêneca (188), pode-se inferir que se verificara a penetraçāo de ideais cinico-estóicos no patrimônio comum do homem do Império Romano. E, neste caso, também participaria dêste acervo a correspondente idealizaçāo da cidade de Roma.

Havia, entretanto, como já fizemos sentir anteriormente, um povo que nāo se unia a tais louvores à Urbe: o povo judeu. E os israelitas revelaram-se adversários dos Antoninos até que se chegasse ao ponto extrêmo do ano 135, quando a dinastia surgiu como inimiga irreconciliável de Israel. De fato, como poderia o "Povo eleito" conformar-se com o universalismo cinico-estóico, quando deveria caber-lhe uma posiçāo excepcional, desde muito profetizada, nos destinos do mundo?

Após os Antoninos, no século III, nota-se a grande influência do estoicismo na evolução do direito romano e, duma ou doutra maneira, ainda que nāo se alimente ilusāo alguma quanto às verdadeiras intenções de Caracala, não se pode deixar de considerar a importância dêste fato para a adoção de uma medida tal como

\footnotetext{
(185). - Trata-se, aliás. de um ponto que confirma a hipótese da grande participacão do estoicismo na inspiracão de Augusto ao fundar o Principado; de fato, aquêles que foram considerados os mais próximos realizadores das idéias de Augusto, eram também orientados por principios estóicos. Nia pior das hipóteses, conclumos que, pelo menos, os planos de Augusto estariam de acôrdo com certos pontos estabelecidos pela, filosofia do Pórtico. Cf. Weber, in "Cambridge Ancient History", XI, págs. 306-307.

(186). - "A JRoma", (60. Cf. Stella, op. cit., pägs. 41, 52, 124, nota 64; Weber. op. cit. pag. 338. Ludley liga mesmo a expressîio "Tdade de Ouro", tão usual para a época dos Antoninos, à filosofia do período: "IBut it is true to say that durinf this period, the Golden Age of the government in the ancient world, philosophy played well its part of adviser and encourager of men of affairs" (op. cit., pág. 156).

(1S7). - Stella, op. cit. pág. 26.

(188). - Idem, idem, págs. 38, 135, nota 117.
} 
se encontra na Constituição Antonina de 212 (189). A crise do III século, abalando a vida romana em todos os seus setores, gerando uma atmosfera tāo diferente daquela que condicionara o aparecimento da oraçāo de Aristides, teria desenvolvido uma nova onda de aspirações à paz, à prosperidade e à compreensāo entre os homens, ideais desde muito ligados à imagem do domínio romano sôbre o mundo e colocados sob a garantia da cidade que, para poder mantê-los eternamente, deveria ser ela própria eterna. Desta vez, entretanto, parece-nos que nāo se ouviram a todo o momento as profecias referentes ao fim da cidade e que se haviam manifestado nos últimos tempos da república. Ao contrário, nota-se no III século uma frequiência inusitada das esperanças seculares, isto $\dot{e}$, das esperanças de que, findo um milênio de sua história, Roma entraria noutro periodo de igual duraçāo; e isto, justamente numa época de enorme miséria material e moral (190). O momento em que tais crenças se evidenciaram de maneira mais clara, foi o que marcou o milésimo aniversário da cidade, de acôrdo com o cômputo de Varrāo. "Tinha-se a persuasāo de entrar verdadeiramente numa nova éra, num novo século, dando à palavra "saeculum" o mesmo valor que Felipe, de século de mil anos. A festa de 248 tinha assim, de certa maneira, o sentido de uma nova fundação, e o culto da fortuna e da eternidade de Roma era, nesta época, um dos grandes recursos morais do Império em desordem" (191).

De fato, a crença na eternidade afirma-se com veemência $e$, após 248 , e as moedas passam a ter cada vez mais freqüentemente nos seus reversos a expressão "Roma AEterna"; é o que se verifica, por exemplo, em 249, com a moeda do usurpador Marinus Pascatianus, pouco depois com Treboniano Galo e Volusiano e, em 253, sob o imperador Emiliano, numa peça em que a imagem de Roma aparece sobrevoada por uma Fênix, com a mesma inscriçāo "Romae aetern(ae)" (192). Estava, assim, completamente

(189). - Cf. Besnier, "L'Empire Romain de l'avènement des severes au concile de Nicée", págs. 65 e ss.; Miller, in "Cambridge Ancient History" XII, págs. 45 e ss.; Hahn, "Das Kaisertum", pág. 9. Toynbee, op. cit., VI, pág. 7; Showerman, "Jternal Rome", pág. 300, estabelece uma verdadeira relação entre a medida de Caracala e o resultado social da propagação do Cristianismo. Partindo de idéia semelhante, assim se expressa Baynes: "It might have seemed that the reconciliation between the Roman State and the Christian Church would be realized through a peaceful evolution and mutual understanding" ("Cambridge Ancient History", XII, päg. 650). Não deixa de ser interessante notarmos, desde já, que o Cristianismo substituiu o Estoicismo na influencia sobre o direito romano, a partir da época de Constantino, confirmando vários de seus princípios e insuflando-lhes nova vida (cf. Riccobono, "L'influsso del cristianesimo sul diritto romano", in "Atti del Congresso internazionale di diritto romano". II, 59-78, ap. Marouzeau, "L'Annés philologique", tomo XIV́, pág. 401).

(190). - Gage, "Recherches sur les jeux séculaires", pag. 111, Toynbee, op. cit., VI, pág. 51.

(191). - Gagê, op. cit. pág. 109. cf. pág. 105.

(192). - Cohen, "MTonnaies de l'empire romain", $v$, págs. 182, 251, 277, ap. Gagé, op. cit., págs. 108-109. Os usurpadores provinciais agiram de maneira semelhante (cf. Jullian, "Histoire de la Gaule". IV, 556-558). Cf. Cochrane, "Cristianismo y cultura clasica", pág. 176. 
firme a crença na eternidade da Urbe, entidade benfazeja, patrocinadora da paz e da prosperidade, sob cujos auspicios todos os povos poderiam sentir-se irmanados numa verdadeira Cosmópolis, crença tāo firme que resistia a tôda a adversidade de um periodo turvo como o III século e que, certamente, devia tal estabilidade aos benefícios e à sabedoria que caracterizaram a época dos Antoninos.

Dissemos antes, entretanto, que os judeus estavam excluidos desta confiança nos destinos de Roma. Vejamos agora como se comportaram os cristãos, depois de São Paulo, em relação ao mesmo assunto.

De maneira geral, quer-nos parecer que o que entāo se verifica com os cristãos é a marcha paulatina para um acôrdo com o Império e, portanto, para a adoçāo da Roma já idealizada pelos pagāos. Os grandes fatôres que entrariam com a maior parte dos elementos preparadores dêste acôrdo seriam, como dissemos acima, de um lado o desenvolvimento do estoicismo no império, apresentando uma série de ideais semelhantes aos dos cristãos, e de outro, a obra de São Paulo, desligando o Cristianismo do Judaísmo essencialmente anti-romano. Os judeus, por sua vez, fecharam-se sôbre si mesmos de maneira rigorosa após o ano 70, passando a hostilizar cada vez mais tudo o que estivesse fora de sua própria doutrina (193), e esta tendência foi ainda reforçada pelos acontecimentos verificados durante os govêrnos de Trajano e de Adriano (194). Isto tornou ainda mais fácil o prosseguimento da obra de Paulo, no sentido de desligar o Cristianismo do Judaísmo; de modo mais decisivo ainda podia a nova religiāo, que nascera no ambiente israelita e fôra considerada uma seita judaica, encontrar elementos para apresentar-se independente do Judaísmo e para caminhar sempre para o universalismo, que a levaria a encontrar-se com os ideais universalistas já pregados pela filosofia helenístico-romana (195).

(193). - Goguel, "La Naissance du Christianisme", págs. 348 e 482; idem, "Les premiers temps de l'ڤglise". pag. 140; idem, "La seconde generation chrétienne", pág. 42; Ricciotti, "Histoire d’Israël", II, pág. 566; Guignebert, "La vie religieuse dans l'empire romain de Néron à Commode". pág. 30; Bonsirven, "Le Judaïsme palestinien au temps de Jésus Christ", I, pág. 40; sóbre o estado de espírito dos israelitas após 70, cf. Simon. "Verus Israel", pág. 19 e ss.

(194) . - Cr. Wendland, "H.R.I." pág. 208, onde o autor nota que o Juciaismo palestmiano venceu e curvou a diáspora sob o dominio do Rabinato. A versão grega da Bíblia foi anatematizada, e o nome de Filo não encontrou lugar nos escritos talmúdicos.

(195). - Cr. Wendland, "H.R.K.", pág. 230: "Die Emanzipation von den nationalen Schranken gibt dem Christentum eine Richtung auf das allgemein Menschenliebe, eine universale Haltung in der die Zukunft seiner Weltmission begrtundet ist." 
Aliás, nota-se desde os Evangelhos uma tendência a apresentar os judeus e nào os romanos, como os autores da condenação de Jesús Cristo, sendo fartamente conhecida a atitude de Pilatos, tudo fazendo para que o Senhor escapasse da morte exigida pelos judeus (196). Este fato é tanto mais significativo quanto "as cousas, na realidade, se passaram de modo diferente. Quaisquer que tenham podido ser as intrigas e manobras às quais entregaram-se os israelitas para determinar a intervenção de Filatos contra Jesús, é certo que todo o processo foi romano, como dá prova a natureza da pena que atingia o condenado e o fato de ter sido executado pelos soldados do Procurador" (197). Ora, a transposição que se encontra nos Evangelhos denota uma dupla tendência filo-romana e anti-judia e o mesmo Goguel - confirmando suposições nossas - acaba por ligar tais traços ao universalismo desenvolvido por Paulo e ao divórcio judeu-cristāo que se seguiu ao ano 70, época em que começaram a ser redigidos os Evangelhos, como se vê: "Nāo se pode complétamente eliminar a idéia de que a deformaçāo da tradiçāo que procurou livrar os romanos da responsabilidade da morte de Jesús foi, de um lado, a conseqüência do anti-judaismo que, após 70, afirmou-se e acentuou-se na tradição da Igreja (198). Nāo se pode, também, afastar a idéia de que ela correspondeu ao desêjo de reduzir uma das dificuldades que obstavam a predicaçāo do Evangelho no mundo romano. Ela parece, entretanto, ter tido caușas mais profundas e ter estado em relação com a atitude nitidamente lealista a respeito de Roma, que foi a da primeira geraçāo do Cristianismo helênico" (199). Quanto à razão dêste lealismo, parece poder ser encontrada, nāo só na "apreciaçāo positiva do Estado por Paulo (200)", mas também em que o Império, já para o apóstolo, teria sido considerado como desempenhando o papel providencial de impedir u'a manifestaçāo prematura do Anticristo, precedido pelas guerras e lutas anunciadas no sermāo profético do Evangelho de Marcos (201), e que a Pax

\footnotetext{
(1.96). - Tertuliano, na, "Apologetica", XXI, 24, assim se expressa: "Pilatos, que èle próprio já era cristĩo no seu coragño..." Cr. Labriolle, "I raction paienne", pags. $327-328$; Waltzing, trad. "Apologetica". nota à pág. 52; Goguel, "La naissance du Christianisme". píg. 476. nota 1: "Ia tendance à charper les juifs et a decharger d'autant les Romains $s$ 'est encore accentuée dans la tradition ultérieurc. Dans l'érangile de Pierre, par exemple, ce n'est pas I'ilate, c'est Herode qui prononce la condannation de jesus et la fait executer. l'jlate se lave les mains,

(197). - Goguel, "La vie de Jesus", pág. 453 e ss., ap. "Lia naissance du Christianisme', pág. 47f.

(198). - Cf. Guignebert, "Ise Christianisme antique", pag. 142-143.

(199). - CE. "Romanos", XIII, 1 e ss.: cf. Wendland. "H.R.TK." ptgs. 246-247; Goguel. "La seconde génération chrétienne, I, pag. 44.

(200). - Idem, idem, pág. 250.

(201). - "Marcos", XIIT, 1. e ss.. Cf. Goguel, "La najssance du Christianisme", pág. 599: "L'idée de ce rôle providentięl du monde présent et, par' suite aussi, de l'Jimpire romain qui en ctait l'expression au premier siècle, doit avoir eté fortement enracinée dans la conscience chrétienne pour que des epreuves comme les massicres de 134 et la persécution de Domitien ne l'en aient pas arrachee, même a Rome qui, pourtant, avait eté le théatre de ces evènements tragiques."
} 
Romana estaria em condições de retardar. Assim sendo, já haveria ai pontos que pudessem servir de base a que Roma, como autora da paz, surgisse aos cristãos como algo de benfazejo, tanto mais quanto a idéia da unidade fundamental do gênero humano encontraria um apôio na unidade de um império mundial (202). Mas o que achamos ainda mais interessante, é o que se encontra num estudo de Dibelius (que, infelizmente, nāo pudemos ter em māos), e que "evidencia uma tendencia do Cristianismo antigo à qual nem sempre se deu a merecida importância, e que foi um dos fatôres da formaçāo do Catolicismo, cuja ambiçāo nāo foi sòmente a de conduzir os fiéis a um Além bemaventurado, mas ainda, a de organizar a vida da humanidade sôbre a terra e servir-lhe de quadro" (203). Ora, é preciso ter-se sempre em mente que havia grandes semelhanças - bem entendido, nāo se trata de identidade entre os principios fundamentais da órganizaçāo da vida sôbre a terra pregados pelos cristāos e os da filosofia cínico-estóica. Já tratamos disto, e julgamos que uma das conclusões imediatas do reconhecimento dêste fato, está em poder-se afirmar com segurança que a difusāo do cinismo-estoicismo constituiu um grande elemento de preparaçāo da própria sociedade romana para a conversāo ao Cristianismo (204). Acreditamos que nāo deixa de ser interessante a êste respeito, o estudo realizado em fins do século passado pelo Prof. Orr sôbre a expansāo da nova Fé na sociedade romana, com o intuito de mostrar a penetraçāo cristā na alta e culta sociedade de Roma mesma. Tal afirmativa, aliás, nāo era completamente nova, desde que Ramsay já dissera que o Cristianismo desenvolvera-se a principio de maneira mais rápida entre os cultos do. que entre os elementos sem cultura (205) mas o que, a nosso ver, dá mérito ao trabalho de Orr é que o autor procura sempre colocar-se numa posiçāo de equilibrio, evitando afirmativas categóricas como a de Ramsay (e que sempre inspiram desconfiança em virtude de sua rigidez); criticando de passagem aquêle juizo, continua Orr dizendo estar persuadido de que mesmo isto está mais próximo da verdade do que a opiniāo frequientemente expressa de que o Cristianismo conquistou a grande massa de seus adeptos nos primeiros tempos, entre pessoas das mais baixas e servis posições,

(202). - Wendland, “MIR.K.", pás. 244, que assim continua: "Jie äusseren Rechtsordnungen, der. gesicherte und lebhafte Weltverkehr, das Strassensystem, dic relative Winheitlichkeit der Sprache und der Zivilisation sind Hussere Nomente, ohne welche die raschen Fortschritte der Mission, das Wandern der Prediger, der lebhafte Austausch der Gemeinden, das rasch sich ausbildende Bewusstsein der Finheit der Kirche unclenkbar sind."

(203). - "Rom und die Christen im ersten Jahrìunciert", ap. Goguel, "La naissance du Christianisme", pás. 599.

(204). - Cf. Bardy, "Isa conversion du Christianisme durant les premiers sidcles", pis. 84.

(205). - "Church in Roman Impire", pug. 37 , ap. Orr, "Neglected factors in the study of the enrly progress of Christianity", peig. 90; cf. Goguel, "La naissance du Christianisme", päg. 577 e ss.." 
que (nas palavras de Gibbon), a nova seita "era quase exclusivamente composta pela escória da populaça, por artífices e campônios, crianças e mulheres, mendigos e escravos;" Dizer que o Cristianismo principiou nas mais baixas classes e que gradualmente subiu na escala social é, na melhor das hipóteses, uma semi-verdade. Não é menos verdade que o Evangelho, frequientemente, apoderou-se primeiro de pessoas em melhor posiçāo social, expandindo-se dai para os lados e para baixo... Muitas vêzes as pessoas de mais alta situaçāo eram as primeiras a vir, e através de seu exemplo, traziam outras (206). Ora, tendo-se em vista a semelhança de ética entre o Estoicismo e o Cristianismo, a enorme expansāo da filosofia cínico-estóica, mòrmente na época dos Antoninos (207) e a aspiração por uma nova Fé que solucionasse os problemas espirituais do homem do Império, aspiração esta que se manifestou de maneira tāo intensa na época dos Severos, nāo parece claro que os cristãos encontrassem já um campo propício à sua expansčo, dado que sua moral era semelhante à da corrente filosófica dominante (208)? - E, aplicando-se tais conclusões ao núcleo do nosso tema, era possivel que, nestas condições, os cristãos pudessem repelir a idealizaçāo de Roma, para cuja construçāo tanto contribuira o estoicismo? - Quer-nos parecer que nāo, ainda mais, julgamos poder afirmar que êste foi o grande fato que permitiu a adoçāo da Roma idealizada por parte dos cristāos, uma. vez que o mesmo Estoicismo que em tāo grande escala contribuira para tal idealizaçāo, tivera também considerável importância na: preparaçāo do campo ao Cristianismo. Aliás, somos de opiniāo que a observaçāo de certas passagens de obras de autores cristāos revela sempre a possibilidade da aceitaçāo da Roma idealizada, nāo só porque há o profundo contacto com a sua base filosófica, mas também porque há o reconhecimento do benefício prestado pela cidade ao Cristianismo nascente. O próprio Tertuliano, que em certo momento escrevera que "nossa doutrina vem de Salomão, que ensinou êle mesmo a necessidade de procurar Deus na simplicidade do coraçāo. Tanto pior para os que inventaram um Cristianismo estóico, platônico, dialético" (209), fôra educado no paganismo, escrevera um tratado - "De Pallio" - em que apresentara o Cristianismo como uma filosofia melhor que as anteriores (210); tal fato, aliás, põe em plena luz a tirania exercida pela educação, mesmo sôbre os espiritos que se haviam completamente entregue ao

\footnotetext{
(206), - Orr, op. cit., págs. 96-97.

(207). - Veja-se, a este respeito, o interessante quadro traçado no "Marco Aurélio", de Renan, cap. III. Cf, Boissier, "La religion romaine", I, pág. 93 e ss..

(208). - Cf. Ueberweg, op. cit., I, pag. 503; Wendland, "HI.R.I.", pág. 91.

(209). - "De Praescriptione", VII, 9-11. Cf. Lebreton, "De la fin du deuxième siecle a la pajx constantinienne", pag. 162, 172-173; Glover, "The conflict of religions in the early Roman Enpire", pag. 337 .

(210). - Cf. Boissier, "La Fin du Paganisme", I, pag. 254.
} 
Cristianismo (211). Era esta educaçāo, fazendo certamente com que o autor reconhecesse as afinidades entre o Cristianismo e muito da filosofia antiga, que o levaria, na "Apologética" (212), mesmo depois de atacar os filósofos, a reivindicar para as Sagradas Escrituras as glórias da filosofia antiga, o que eqüivale, de certa maneira, a colocá-la em relação com o Cristianismo; ainda isso é responsável por uma frase famosa e particularmente interessante para nós: "Seneca saepe noster" (21.3), o que confirma o reconhecimento das afinidades com a filosofia da época por parte da moral cristā; mais notável ainda, pelo seu sạbor cinico-estóico, é a seguinte afirmativa do mesmo autor: "Nāo conhecemos senāo uma só república, comum a todos: o mundo" (214).

Nestas condições, recaimos no mesmo ponto a que chegamos quando tratamos do estoicismo: qual a entidade que melhor permitira uma concretizaçāo que mais se aproximasse dêste ideal? Roma, pela paz e pela progressiva homogeneizaçāo do Império, o que facilitava a expansāo do Cristianismo, uma vez que "todos os países sāo accessiveis, tôdas as regiões conhecidas:... Campos cultivados domaram as selvas...; semeiam-se as areias, talham-se as rochas, dessecam-se os pântanos; ali há mais cidades hoje do que cabanas outrora. Agora já nāo assustam as ilhas, nem os escolhos incutem terror; em qualquer parte há meios de se habitar, em qualquer parte está a populaçāo politicamente organizada, em

(211). - Idem, idem, pág. 258.

(212). - XLVI e XIVII. Cf. Hochart, "Itudes sur la vie de Seneque", pag. 38.

(213). - "De Anima", 20 ; cf. Glover, "The world of the New Testament", pag. 82; Barth, op. cit., pág. 288.

(214). - "Apologetica", XXXVIII, 3. I nota-se que os imperadores estóicos, os Antoninos, são bem afastados de qualquer acusacão, como se vê na "Apologetica", $v$, em que o autor, após referir-se a atitude anti-cristā de Nero e' de Domiciano, assim se expressa: "Mas entre tantos príncipes que se seguiram até os nossos dias, de todos os que entendiam de cousas divinas e humanas, citai um só que tenha feito guerra aos cristãos! Nós, ao contrário, podemos citar entre éles um protetor dos cristãos, se quizermos recorrer a carta de Marco Aurélio, êste sapientíssimo imperador, em que êle atesta que a sêde cruel que desolava o exército da Germania foi amenizada por uma chuva, que caiu graças às preces de soldados que eram, casualmente, cristãos. Se êle não revogou abertamente o edito de verseguição, abertamente neutralizou ele os seus efeitos de outro modo, ameaçando mesmo os acusadores de uma pena, e pena mais rigorosa ainda, que pensar então destas leis que apenas os principes impios, injustos, infames, cruéis, extravagantes e insensatos executam contra nós, leis que Trajano contornou em parte, proibindo de se procurar os cristãos, que jamais Vespasiano fêz aplicar, se bem que ele fósse o destruidor dos judeus, jamais um Adriano, perscrutador de tódas as cousas curiosas, jamais, um Antonino-o-Pio, jamais um Vero? - E entretanto, era muito mais natural que celerados fossem externinados pelos melhores príncipes, seus inimigos naturais, do que por seus semelhantes'. Cf. Harnack, op. cit., pág. 196, nota 1 ; Labriolle, "La réaction paienne", pág. 73: "Telle fut la these chrétienne: une solidarité lie les destinées de Rome et celles du caristianisme; toutes les fois que Rome a langui sous des mauvais empereurs, le christianisme a été persécuté dès qu'elle s'est épanouie sous des princes justes et bienfaisants, aussitót la paix a été rendus aux églises." Idem, "Histoire de la litterature latine chrétienne", pág. 83: "Il a, du reste, beaucoup emprunté à la philosophie profane, surtout au stoïcisme", cf. pág. 102; Wondland, "H.R.K.". pág. 94; Barth, op. cit., págs. 290-291. 
qualquer parte está o estado, em tôda parte está a vida civilizada" (215).

Sāo Cipriano, por sua vez, tāo ardoroso defensor da preponderância da sede de Roma sôbre tôda a Cristandade, nāo deixara de ter seus contactos com Sêneca (216), e à maneira cristā - é claro - admitia a idéia da permanência em Roma, senāo eternamente, pelo menos enquanto durasse o mundo; tal modo de pensar transparece na sua obra através de preocupaçāo com o fim do mundo (217), parecendo sempre que o que lhe dá a impressão da sua proximidade é a situaçăo do Império, em plena. crise, levando automàticamente para o seu fim a cidade de Roma.

Também entre os autores de lingua grega notam-se fatos interessantes durante o século III. Orígenes, respondendo a Celso, afirma a intençāo divina de, por intermédio de Roma, preparar a humanidade para a recepçāo de Jesús Cristo; "Deus teria preparado as naçôes para o Seu ensinamento, fazendo com que elas estivessem sob um imperador romano e nāo sob a. forma de muitos Estados, sem que as nacionalidades estivessem ligadas entre si, o que tornaria muito difícil a execuçāo da tarefa de que Jesús incumbiu os apóstolos quando disse: "Ide e ensinai tôdas as naçóes" (218).

Com Latâncio, por fim, chegamos ao período em que o reconhecimento do Cristianismo por Constantino acabaria afastando qualquer obstáculo à adotação de Roma idealizada por parte dos cristāos e, como sempre, encontram-se na obra de Latâncio os mesmos traços já referidos em relaçāo à outros autores: influências estóicas e admiraçāo pela cidade, de tal modo que somos quase levados a afirmar que o estoicismo era um caminho inevitáel para a idealização de Roma (219). Já vimos antes como Latâncio refere-se a Roma, e basta acrescentarmos agora que tal autor, cha-

(215). - "De Anima", $\mathrm{XXX}, 3$.

(216). - Labriolle, "De l'unité de l'eglise catholique", pág. XI, 52, nota 10; idem, "Histoire de la littérature latine chrétienne", pag. 209, 214; Boissier, "I a fin du paganisme". I. pág. "2, in.

(217). - Cf. Laluriolle. "De l'unité de l'Eglise cathulique", pág. 33; "Ad Demetrianum", IV, 5: "... ninguem se deve admirar de que tucio no mundo comece á definhar, quando o próprio mundo todo está cm degenercscência e no fim. $E$ porque as guerras continuam amiudadamente; porque a esterilidade $e$ a fome aumentam as afliçôes: porque a saúde e aniquilada pelas doenças embravecidas; porque, sendo devastado o gênero humano, serás castigado com a populaçào e fíca sabendo que jsto estava predito; que, nos últimos tempos, multiplicar-se-iam os males..." Cf. Cochrane, "Cristianismo y cultura clasica", pág. 157.

(218). - Peterson, "Der Nonotheismus als politisches Problem", pág. 66. A.obra. pacificadora de Augusto é tambem invocada por Origenes: cf. Peterson, op. cit., pags. (77-6S: "Wie wiare os dann aber möglich pewesen, dass eine so friedfertige J,chre vie die des Christentums, die nicht cinmal erlaubt, sich gegen Fcinde zu welren, Macht gewinnen konnte, wenn nicht allenthalben in der Oiliumene mit Jesu Ankunft schon eine Wendung zum Gositteren eingetreten wire?". Cf. Dimielou, "Origene", pág. 228 e ss.; Harnack, op. cit., pág. 13; Labriolle, "Lá réaction paienne", pag. 150; Riber, "Aurelio Prudencio", pag. 94.

(219). - Notemos que Comodiano, que não parece te: tido contacto com o IEstoicismo, foi também completamente contrário a Roma. 
mado por Sāo Jerônimo de "o Cícero cristāo" - o que revela o grau de suas relações com a cultura pagã (220) - era de tal maneira impregnado de estoicismo que escrevera uma obra, "De opificio Dei", que "se poderia tomar por um trabalho de um estóico, visto conceder, acima de tudo, considerável espaço a uma polêmica contra os epicuristas que negavam a Providência" (221), e que, nas "Divinas Instituciones", apoiara-se nos estóicos para ir contra os filósofos que nāo admitiam a Divina Providência (222). Havia sempre, portanto, a aproximaçāo com o Estoicismo, de tal modo que os cristāos pudessem partilhar com os neo-platônicos a herança da Estoa (223). E êste fato, com tôdas as consequêencias dêle• decorrentes, entre as quais a que diz respeito à ligação com o Império e com a aceitaçāo de Roma idealizada, só se tornara possível, evidentemente, graças à ruptura dos Cristãos com o Judaismo e à sua marcha decisiva no caminho universalista. Eis porque dissemos que na obra de São Paulo residia o ponto de partida para a transmissāo da idéia de Roma para a esfera cristā.

(Continua no próximo númeto)

\author{
PEDRO MOACYR CAMPOS \\ Livre-docente e assistente da Cadeira de His- \\ tória da Civilizagão Antiga e Medieval
}

(U.S.P.).

(220). - Pichon, "Lactance", ap. Romeyer, "La philosophie chrétienne jusqu'a Descartes", II, pág. 144; Cochrane, "Cristianismo y cultura clasica", pág. 47.

(221). - Ebert, "Histoire générale de la littérature du Moyen Ãge en Occident", I, pág. 85.

(222). - Idem, idem, pág. 87 ; cf. págs. 95 e 96 ; “... il avait, selon toutes les apparences, sacrifie auparavant au stoicisme".

(223). - Cf. Ueberweg, op. cit., I, pag. 503: "Winige Generationen nach Mark Aurel finden wir den Stoizismus wie anders Sjsteme aufgesogen durch den Neuplatoniemus. In ihm lebt vieles von stoischer Doktrin bis auf spätere Zeiten fort. Mit dem Neuplatonismus teilt sich die christliche Patristik in die Vermittlerrolle. So gering der Einfluss des Stoizismus auf das Neue Testament ist, so stark hat er auf die Kirchenviater cingewirkt. Vor allem ist anzuerkennen dass er durch seine Ethik und Teilweise auch durch seine Theologie der Entwickung und Verbreitung des Christentums den Boden geebnet. hat." Cf. Arnold, ar. "Stoics" in "Incyclopedia of Religion and Jithics"; Showerman, "Eternal Roma", pág. 297. O cinismo foi também absorvido pelo Cristianismo: cf. Caster, op. cit., pág. 65. A respeito das relacōes entre cinismo e Cristianismo, veja-se Dudley, op. cit., págs. 174, 204-206 e o Epílogo: cf. Murray, op. cit., págs. 57-58. 